\title{
Imágenes devocionales en las iglesias misioneras jesuitas de Mojos (Bolivia), a la luz de los inventarios de la época de expulsión
}

\author{
Ewa Kubiak \\ Universidad de Lodz, Polonia
}

Instituto Polaco de Investigación del Arte Mundial

\section{Jesuitas misioneros en el Perú y misiones en la región de Mojos}

En el Perú, antes de la llegada de los jesuitas, se desempeñaron las órdenes de los dominicos, franciscanos, agustinos, mercedarios y el clero secular. En 1566, el padre general de la Compañía de Jesús, Francisco de Borja, aceptó la solicitud de Felipe II de enviar a jesuitas a Florida y al Perú. En marzo del año siguiente, nombró a Ruíz de Portillo como provincial de todos los territorios indianos, es decir, las colonias subordinadas a la Corona ibérica. El grupo de los jesuitas bajo su cuidado y dirección salió de Sanlúcar de Barrameda en noviembre, llegando a Lima a principios de abril de $1568 .{ }^{1}$ Durante la época colonial, de España a los virreinatos americanos, llegaron más que 3000 ignacianos, tomando en cuenta a los extranjeros, principalmente italianos y alemanes ${ }^{2}$.

${ }^{1}$ En los territorios americanos hispanohablantes hasta el año 1572 funcionaba la única provincia de los jesuitas. Pronto hubo división de la Provincia de Indias Occidentales (1572) en la parte norteña (México) y el sur (Perú), Nieto 2001: 3105. Después en América del Sur fue creada la Provincia de Paraguay (1604), Provincia de Nuevo Reino de Granada (1611), de Chile (1683), de Quito (1696), Burrieza SÁnChez 2004: 201-209.

2 Zaballa Beascoechea, Paniagua Pérez 2012 [2006]: 433. 
Las iglesias jesuíticas desempeñaban diversas funciones. La misión evangelizadora y sacerdotal de los jesuitas concernía tanto a la creciente sociedad urbana como a las áreas rurales de los Andes, lejanas e inaccesibles, además de algunas regiones tropicales de la costa y del interior. ${ }^{3}$ Las primeras reducciones se establecieron en el Paraguay, cuyo trabajo de evangelización comenzó en 1595. Para poder extender sus misiones al norte de Santa Cruz, los jesuitas fundaron un colegio en dicha ciudad, convirtiéndose en el centro de evangelización en las fronteras con los territorios de los infieles.

El primero en establecer contacto con los Mojos fue el hermano Juan de Soto, durante una expedición emprendida en 1667. Años después, los jesuitas volvieron para evangelizarlos. Entre los misioneros, debemos destacar a Julián de Aller. Como nos informan José de Mesa y Teresa Gisbert, Aller junto con el padre Bermudo y otros dos jesuitas "recorrieron parte de la región durante dos años y evangelizaron diversos grupos aprendiendo la lengua a fin de hacer su labor más efectiva"4. En 1682 se fundó la primera misión ${ }^{5}$ de Nuestra Señora de Loreto. Desde ese momento empezó el desarrollo intensivo de la obra misionera y siguieron las fundaciones de otras reducciones.

El territorio de Mojos se extiende en el actual departamento de Beni, al noroeste de Bolivia. La región está delimitada al norte por el río Iténez, al oeste por el río Beni y al sur por la selva, la cual constituye una frontera natural con la región de Chiquitos. Es una zona tropical, extremadamente húmeda y rica en vegetación. Las misiones fundadas en Bolivia fueron La Trinidad (1686), San Ignacio (1689), San Francisco Javier (1690), San Francisco de Borja (1693), San Pedro (1697), Nuestra Señora de la Concepción y San Joaquín (1708), La Exaltación de la Cruz y Santa Ana (1709), Magdalena (1720) ${ }^{6}$ [fig. 1]. Las últimas misiones fueron fundadas durante los años cuarenta: San Nicolás (1740) y San Simón (1744). Dos reducciones (Santa Rosa y San Miguel) se ubicaron más distantes, al oriente, y tuvieron que ser abandonadas para cumplir un tratado sobre la frontera firmado entre España y Portugal. ${ }^{7}$ En su mayoría, las iglesias fueron edificadas con adobe y recubiertas con madera. Se componían de tres naves y fueron adornadas con altares enriquecidos por esculturas y pinturas.

3 Incluso en las iglesias urbanas, se construyeron capillas separadas para los indígenas (como en Bogotá o Cusco), con el fin de saciar las necesidades espirituales de todas las capas sociales.

4 Mesa, Gisbert 2002: 258.

5 En el texto se usa los términos „misión” y reducción” como sinónimos.

${ }^{6}$ Mesa, Gisbert 2002: 258-267.

7 Mesa Gisbert, Mesa, Gisbert 2012: 202. 


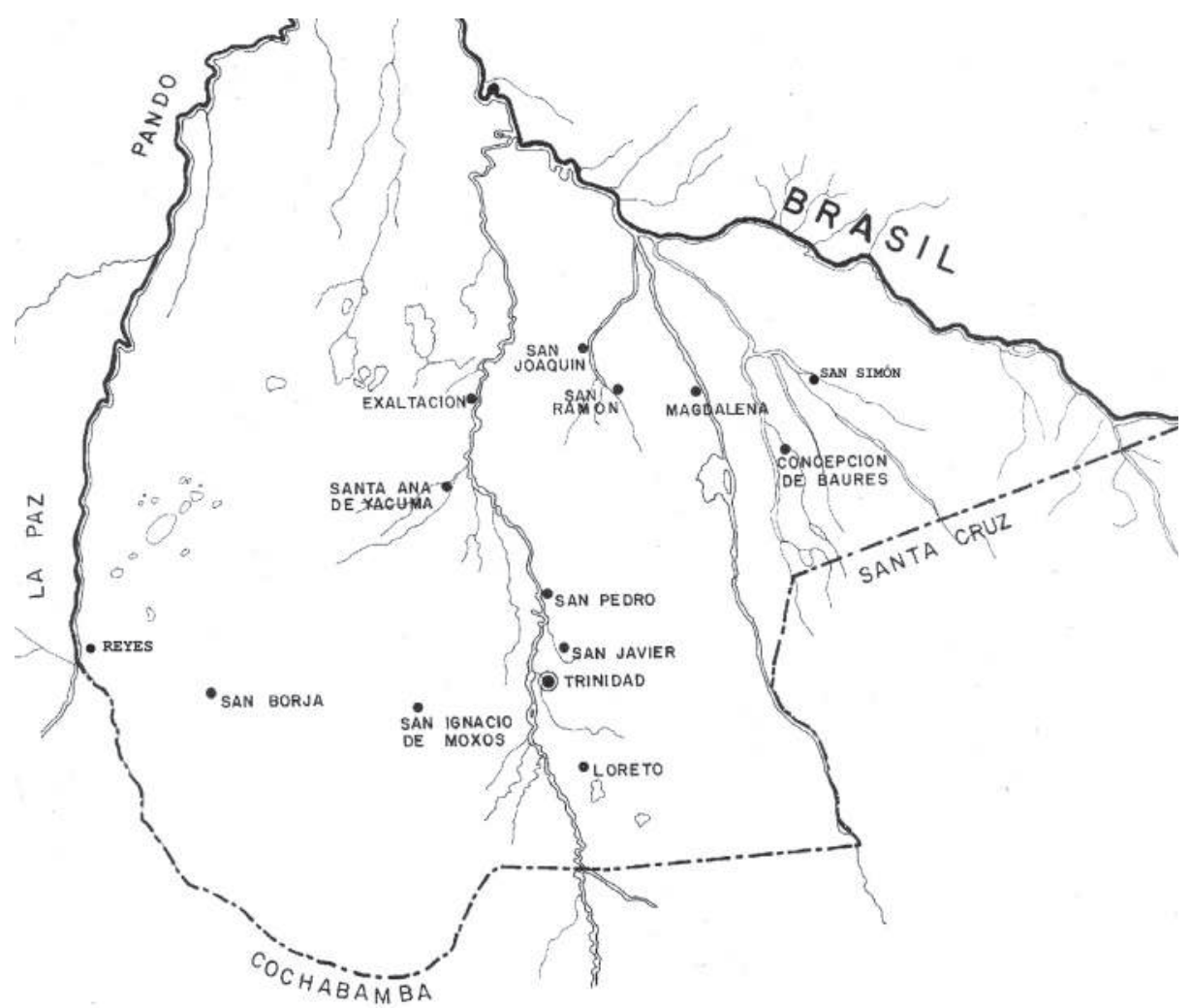

Fig. 1. Mapa de las Misiones de Mojos [Mesa y Gisbert 2002: 261] con observaciones de la autora.

En los tiempos post-jesuíticos, el destino de estas iglesias fue completamente desafortunado. Todas fueron destruidas. Hoy las conocemos solamente por relatos y algunas imágenes de la época. [fig. 2] La expulsión de los jesuitas de los territorios sudamericanos subordinados a la Corona española, se dio a partir del decreto firmado por Carlos III en $1767 .{ }^{8}$ Desde ese momento se gestaron los inventarios de los bienes jesuitas, con el fin de dividir los bienes o entregar las iglesias a la tutela del clero secular. La decisión de expulsar a los jesuitas de los territorios americanos conllevó consecuencias negativas en múltiples aspectos. En las regiones distantes, la evangelización y el servicio sacerdotal mermaron, así como la atención a los centros educativos a cargo de los iñiguistas. Los talleres artísticos que se desarrollaban bajo su cuidado fueron abandonados. Al respecto, Guissela Jurado de Guerra escribe sobre

${ }^{8}$ Fueron expulsados más de cinco mil jesuitas en toda la monarquía hispánica, BAPTISTA 2001: 1353. 
la destrucción de la herencia cultural y apostólica de los jesuitas, ${ }^{9}$ cuyo destierro afectó a las misiones sudamericanas por la dificultosa adaptación de sus actividades. Por ejemplo, en la relación anónima de los terrenos misioneros de Chiquitos de 1768, leemos sobre numerosas inconveniencias relacionadas con la necesidad de incorporar los territorios remotos al clero secular. En el relato la característica general de la arquitectura sacra de la región fue interrumpida por un interesante comentario sobre problemas con insectos, que daban grandes "inconveniencias", "matan el cuerpo (...) y devoran las telas", ${ }^{10}$ las vestimentas litúrgicas y los libros guardados en las sacristías. ${ }^{11}$ El sucesivo abandono de las misiones fue una infortunada consecuencia de los problemas de adaptación de los seculares a las condiciones adversas de la región, particularmente en las iglesias locales más lejanas, las cuales fueron llevadas a la ruina y, finalmente, "desaparecieron".

Cabe destacar que los actuales habitantes de los pueblos, aunque hayan transcurrido una considerable cantidad de años, tratan de subrayar su tradición jesuítica. Por ejemplo, en San Ignacio, construyeron una nueva iglesia, o mejor dicho, la "reconstruyeron". Los materiales empleados cambiaron, pero la forma del edificio recuerda a los templos de época virreinal. Igualmente, los altares, sus esculturas, ornamentos y pinturas siguen la tradición artística de la región. Edificios posteriores como la iglesia de San Ignacio nos permitirán reconocer las imágenes religiosas jesuitas de la época colonial que analizaremos más adelante. ${ }^{12}$

9 JuRAdo de Guerra 2003: 1551.

${ }^{10}$ Archivo y Biblioteca Nacional de Bolivia (ABNB), Mojos y Chiquitos (M. y Ch.), GRM, vol. 24, II, f.8r.

${ }^{11}$ El mismo autor, posteriormente también se queja de los problemas de comunicación con los habitantes de las reducciones. Las regiones de Mojos y Chiquitos fueron famosas por su "riqueza y diversidad lingüística" [EDER 1985 [1772]: 42]. Lo mismo confirma Carlos Bravo: "en Santa Cruz y el Beni se usa multitud de dialectos, según los pueblos y parcialidades" [BRAVo 1894: 104]. Muchas de estas zonas de evangelización tenían poco tiempo de haber surgido, los indígenas aún no aprendían español y, en realidad, no había premura por ello, puesto que los misioneros hablaban las lenguas locales. Para el clero secular, el viaje a una zona húmeda, lejana y con insectos que dificultaban la vida, debió ser sumamente desagradable; aunando los grandes problemas de establecer contacto con los indígenas. Regularmente, antes de partir a los territorios de misión, los sacerdotes "reclutaban" traductores. Pero, tal y como nos informa un relato de la época sobre Santa Cruz, cuando querían contratar algunos, éstos "fueron pocos y muy corta inteligencia" [ABNB, M. y Ch., GRM, vol. 24, II, f.11v.]. Por consecuencia, para el sacramento de la confesión, los sacerdotes se veían obligados a utilizar una lista de preguntas y respuestas traducida a la lengua local. No obstante, también chocaban con la dificultad de la pronunciación, particularmente con los sonidos nasales y de garganta („,más se explican con las narices y garganta” [ABNB, M. y Ch., GRM, vol. 24, II, f.12r]).

12 Sobre las nuevas iglesias en las antiguas misiones, véase: [BeCERRa CASANOvas 1984]. El autor describe la situación de los pueblos y sus templos en los años ochenta del siglo XX, 

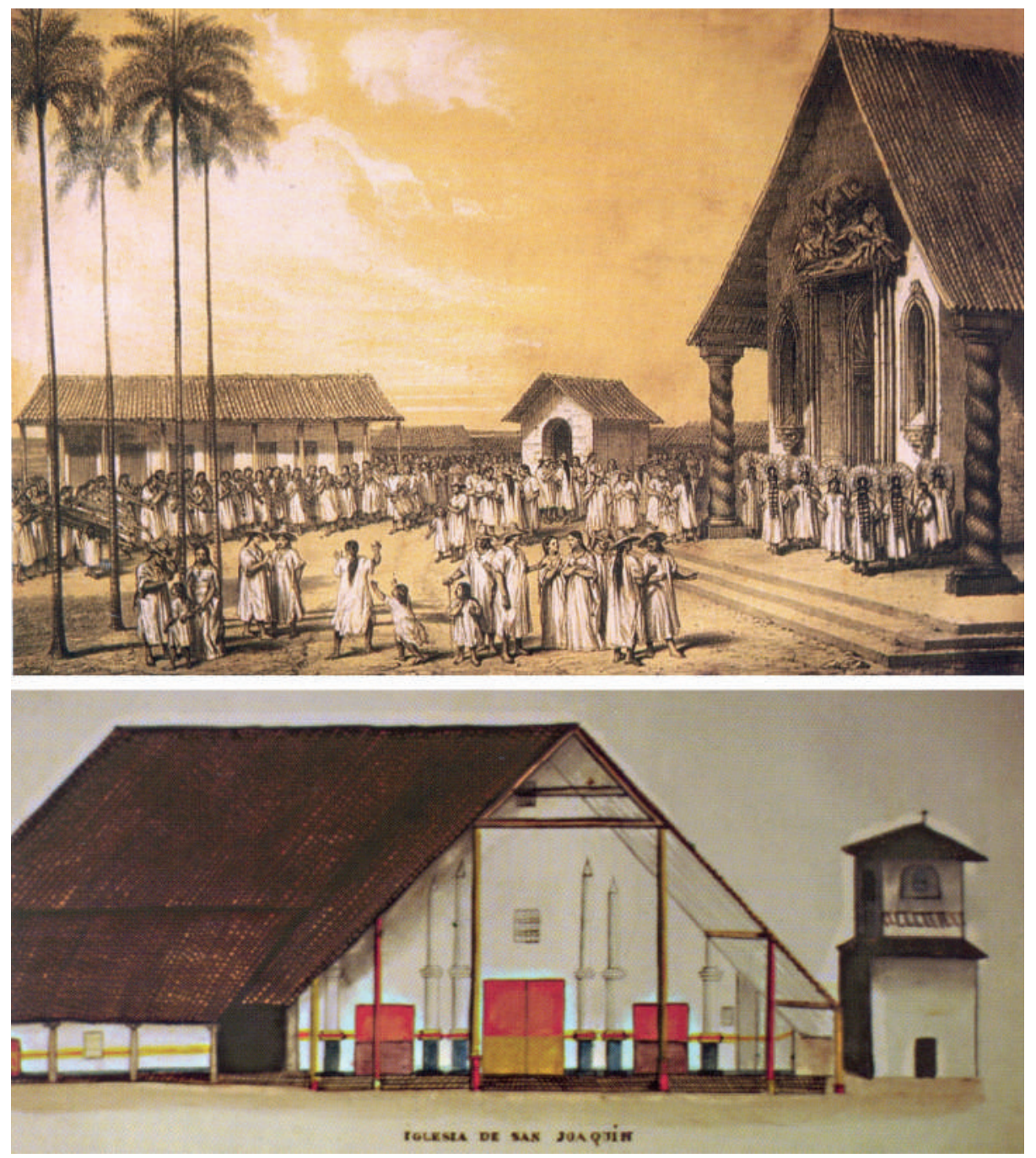

Fig. 2. Procesión en una reducción de Mojos según un grabado del siglo XIX; la desaparecida Iglesia de San Joaquín de Baures [MeSA Y GiSBERT 2002: 260].

resaltando los elementos coloniales que se preservaron en los nuevos templos. Actualmente, el estado de los inmuebles ha cambiado mucho. Por ejemplo, en San Ignacio podemos admirar la nueva iglesia y las obras coloniales en un museo parroquial al lado del templo. 


\section{Culto de LAS IMÁGENES Y EL PROCESO DE EVANGELIZACióN}

Las imágenes de culto constituyen un elemento clave en la religiosidad católica. En la historiografía, es común decir que el momento decisivo en la aceptación e implementación sistemática del culto a las imágenes en el mundo moderno, es la puesta en marcha de los decretos tridentinos. Pero desde hace tiempo atrás, diversos teólogos avalaron la presencia de las imágenes en los templos y su importancia para el culto. Para justificar su opinión, se remitieron a la tradición de la Iglesia católica y la voluntad de los fieles. Berthold Pistringer von Chiemsee y Konrad Braun encontraron en las obras patrísticas numerosa información sobre el significado e importancia del arte en el fortalecimiento de la fe de los primeros cristianos. En Francia, durante el sínodo en Sens (1528), se defendió el uso de obras artísticas en las iglesias. En 1562 Guillaume Morel presentó en Silvae locorum, diversas citas de las obras de los padres de la Iglesia, donde se demostraba la antigüedad y los efectos beneficiosos del arte sacro. Dos años más tarde, René Benoist argumentó que los verdaderos adoradores de Dios se fortalecieron en la fe mirando las iglesias y las imágenes que las adornaron. ${ }^{13}$ También, en las opiniones de los teólogos italianos (Luigi Lippomano, Alberto Pio, Gabriele Paleotti), podemos encontrar explicaciones parecidas, donde trataron de subrayar los efectos beneficiosos del arte para los fieles contemporáneos. ${ }^{14}$

La culminación de la discusión sobre el culto de las imágenes sucedió a través del decreto segundo de la sesión 25 del Concilio de Trento (el 3 de diciembre 1563), referente al culto a las reliquias e imágenes sagradas (De invocatione, veneratione et reliquiis sanctorum et sacris imaginibus) ${ }^{15}$ Dicho decreto inicia con las siguientes palabras:

El santo sínodo exige de todos los obispos (...) la instrucción de todos los creyentes en la apelación a los santos, su invocación, la veneración de las reliquias y el uso correcto de las imágenes, por supuesto siguiendo las costumbres transmitidas desde los primeros tiempos de la religión cristiana de la Iglesia Católica y Apostólica, conforme al consenso de los santos padres y las resoluciones de los santos concilios. ${ }^{16}$

\footnotetext{
13 Para más información sobre la disputa en torno a las imágenes en las iglesias francesas, véase: KRASNY 2016.

${ }^{14}$ Krasny 2010: 25-29.

15 Para consultar el texto en latín y la traducción polaca de todos los documentos del Concilio de Trento, véase: DSP 2007: 780-785.

16 Veneración 2012 [1563]: 721. Mandat sanca synodus omnibus episcopis [...] ut iuxta catholicae et apostolicae ecclesiae usum a primaevis christianae religionis temporibus receptum, sanctorumque patrum consesionem et sacrorum conciliorum decreta: in primis de sanctorum
} 
Y en el siguiente párrafo leemos: "Las imágenes de Cristo, de la Virgen Madre de Dios y de los demás santos deben permanecer en las iglesias tal como se encuentran ahora y ser objeto de los honores y veneración (honorem et venerationem) debidos." ${ }^{17}$ Este decreto, aunque trató también de las reliquias, en su mayoría fue dedicado a las imágenes. Las representaciones sagradas debían ser decorosas y carecer de falsos contenidos y enseñanzas. ${ }^{18}$ Cualquier nueva iconografía representada en las obras de arte, debía ser aceptada y confirmada por los expertos eclesiásticos y, finalmente, por las instancias superiores del clero. Desde una nueva mirada, las imágenes atrajeron el interés de los investigadores. Por ejemplo, Hans Belting elaboró una historia de la imagen antes de la era del arte. Él entiende como "imagen" a las imágenes del culto particular que aún no están fuera de las ideas de una obra del arte no tienen que ser las mismas. La función, uso devocional y prácticas religiosas relacionadas con las imágenes del culto son más importantes que su forma. ${ }^{19}$

En Europa, las imágenes funcionaron como una herramienta de "recatolización" de la sociedad, ${ }^{20}$ frente a los embates y contacto con el protestantismo; mientras que en América fue un elemento trascendental en el proceso de evangelización. Basándose en los pilares del catolicismo, los religiosos españoles que llegaron al Nuevo Mundo eligieron la obra de los apóstoles como su máxima inspiración. Según las palabras de San Pablo: "La fe entra por el oído" (Rom 10,17). Es decir, la fe proviene de la audición y la fuerza persuasiva de los sermones. En el caso de América, muy a menudo, predicación e imágenes armonizaron como instrumentos de evangelización. ${ }^{21}$ También las imágenes acompañaron a los textos escritos haciendo su contenido religioso más comprensible. ${ }^{22}$ Los jesuitas tenían plena conciencia del poder de las imágenes y usaron el arte en su obra misionera como una de las herramientas más importantes para ejercer su labor. Una contribución muy concreta a la iconografía de los siglos XVII y XVIII fue, por ejemplo, la edición ilustrada de la Evangelicae Historiae Imagines (1593) de Jerónimo Nadal. En el libro se relacionan

intercessione, invocatione, reliquiarum honore et legitimo imaginuj usu fideles diligenter instruant. [DSP 2007: 780].

17 Veneración 2012 [1563]: 721; Imagines porro Christi, deiparae Virginis et aliorum sanctorum, in templis praesertim habens et retinendas, eisque debitum honorem et venerationes impertiendam.; DPS 2007: 780.

${ }^{18}$ La primera aceptación del uso oficial de las imágenes tuvo lugar durante el Concilio de Nicea II (787), donde se promulgó que las imágenes no serían prohibidas y que éstas podían ayudar en el desarrollo de la piedad. O'Malley 2014 [2013]: 262.

19 Belting 2012 [1990]: 5; Baumgarten 2004: 127.

20 Baumgarten 2004: 139-140

${ }^{21}$ GonzÁlez García 2015: 250-279. Sobre el uso de las imágenes como apoyo para la predicación, véase también: Mujica Pinilla 2002: 219-313; Mujica Pinilla 2006: 41-65.

22 GonZÁLEZ SÁNCHEZ 2016: 255-276. 
los grabados con las meditaciones del ciclo litúrgico anual. Las ilustraciones de este volumen sirvieron como fuente para la pintura desde Italia, surcando por toda Europa; hasta el Perú, Goa y Japón. Otros jesuitas propagaron el uso de las imágenes, como Roberto Belarmino, Antonio Possevino, o algunos de los primeros defensores de las imágenes devocionales, los padres generales Francisco de Borja (1565-1572), Claudio Aquaviva (1581-1615) y Juan Pablo Oliva $(1661-1681){ }^{23}$

\section{IMÁGENES DEL CULTO EN LAS IGLESIAS MisionerAS DE MoJOS}

En las iglesias misioneras de los jesuitas en la región de Mojos, Bolivia, podemos encontrar tres tipos de imágenes. El primer grupo lo constituyen las imágenes características de la época postridentina, es decir, representaciones de Cristo, la Virgen, los santos y escenas del evangelio. El segundo grupo lo conforman las imágenes de los santos iñiguistas. Y, finalmente, al tercer grupo pertenecen las representaciones y advocaciones típicas del virreinato peruano.

Las primeras descripciones de las reducciones aparecieron junto con el establecimiento de las misiones jesuitas en la región de Mojos. En estos relatos no se mencionan las imágenes de culto, aunque Julián de Aller (1670) demostró la profunda religiosidad de los indígenas y la ausencia de idolatrías. Subrayó también la importancia del conocimiento de la lengua local indígena. El jesuita relató que los indios "no tienen rostro de idolatría ni adoración alguna; conocen a Dios y confiesan su divinidad; a Dios le llaman Maymona, que según la frase de su lengua, vale 'el que lo mira'. Nuestro Señor me ha dado tal presteza en percibirla, que la puedo hoy enseñar; la copia no la tengo; esa costará el trabajo". ${ }^{24}$

\section{ADVOCACIONES GENERALES}

Como hemos expuesto, los siglos XVII y XVIII constituyen una época muy particular para el culto de las imágenes. La vida religiosa en las reducciones indígenas de Mojos fue de gran fervor y las imágenes de culto proliferaron con el paso del tiempo. Las representaciones de Cristo crucificado, la Madre de Dios y/o los santos, se empleaban durante los ritos cotidianos y festivos. [figs. 3-4] En cada reducción, tanto según los relatos como los inventarios,

23 Bailey 2003: 126-127; Bailey 2009 [2003]: 10-12; Pfeiffer 2003: 171.

${ }^{24}$ AlLER 2005 [1670]: 37. 
particularmente se subraya la devoción a la Virgen María. Por ejemplo, Diego de Eguiluz (1696) relató que los indígenas:

De la Santísima Virgen son amantísimos y nunca la nombran sino diciendo: Nuestra Madre. Ya dije la asistencia particular de los sábados a sus Iglesias, a toque de campana, a Salve, Letanía y después de rezar a coros su Santísimo Rosario, invocándola en sus necesidades con grande fe; (...) Con tanta sencillez van, antes de cazar, a despedirse a las Iglesias de su Santa Imagen y en voz alta, con su mal limada retórica, representar con notable confianza sus necesidades y trabajos, pidiéndole ayuda y que disponga que encuentren algo qué flechar y traer a su casa para su sustento y el de su familia. ${ }^{25}$

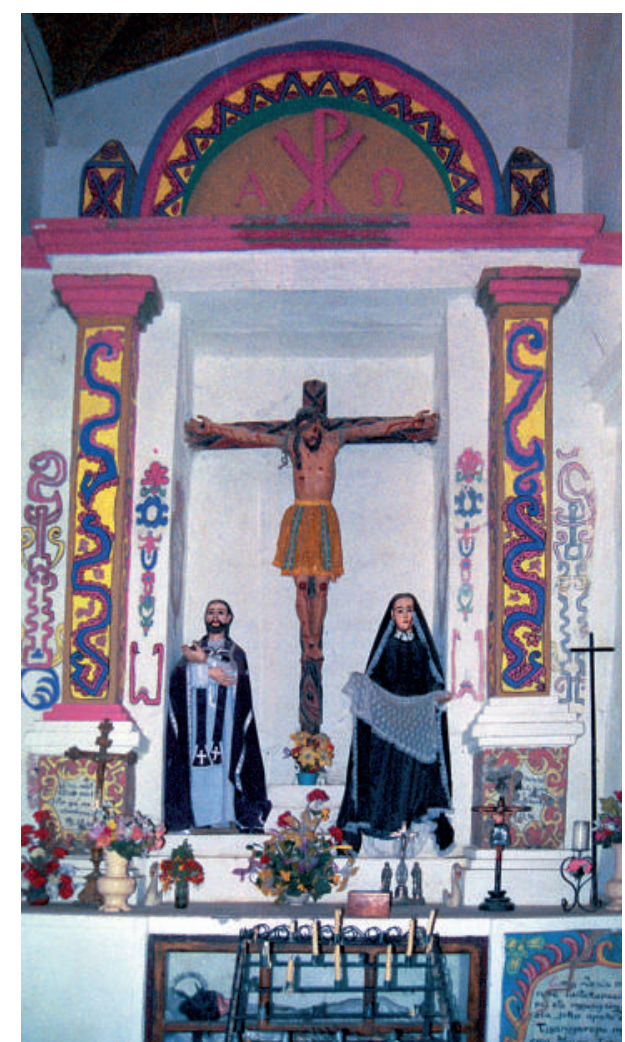

Fig. 3. Altar lateral de la Crucifixión de Cristo, anónimo, siglo XX, Iglesia San Ignacio de Mojos [fot. E. Kubiak, 2004].

${ }^{25}$ Eguiluz 2010 [1696]: 64. 


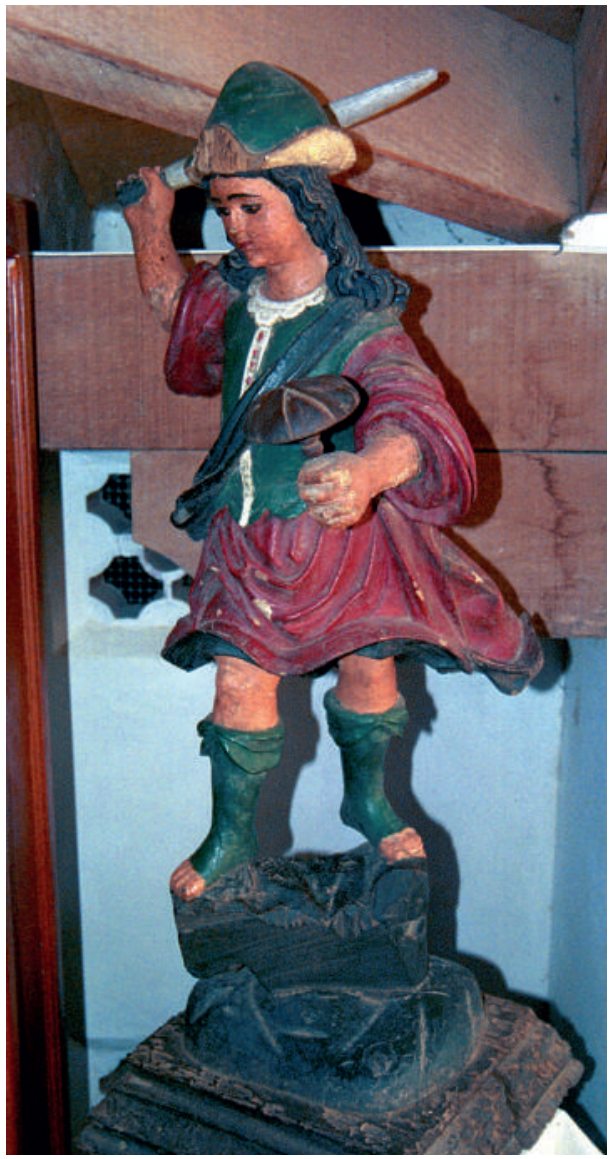

Fig. 4. San Miguel Arcángel, anónimo, siglo XVIII(?), escultura en el museo parroquial de San Ignacio de Mojos [fot. E. Kubiak, 2004].

Pedro Marban (1700) también menciona que "los domingos por la tarde salen todos en procesión con una imagen de la Santísima Virgen" y "los sábados por la mañana se canta la misa de la Santísima Virgen con variedad de tonos músicos". ${ }^{26}$ Durante la Semana Santa se describe el culto relacionado con

${ }^{26}$ Marban 2005 [1700]: 63. En el mismo tenor de los relatos anteriores, otros misioneros escribieron sobre las costumbres pías en las reducciones. Diego Francisco Altamirano menciona que "los domingos por la tarde salen todos en procesión con una imagen de Nuestra Señora, cantándole su santísimo rosario por las calles del pueblo" y "los sábados por la mañana se canta la misa de la Santísima Virgen con variedad de tonos músicos; por la tarde la Salve y Letanía, rezando después el Rosario a coros.” Altamirano 2005 [1713]: 72. Alberto de Quintana relata que los indios "son muy extremosos en la asistencia de la Misa cotidiana por la mañana y por la tarde el Rosario"; Quintana 2005 [1756]: 154. 
las figuras de Cristo y la Virgen. Eguiluz nos informa que los indígenas llevaban "en unas andas la Imagen de bulto de Cristo Crucificado y en otras la de la Santísima Virgen, también en bulto". La celebración del Jueves Santo empezaba con la "adoración de la Santa Cruz" y los ritos del Viernes Santo acababan con reverencia "a vista de la Imagen de Cristo Crucificado". ${ }^{27}$ Es así como en cada relación se subraya la importancia de la celebración de "la Pasión de Nuestro Salvador". ${ }^{28}$

En la misión de San Francisco Javier estaban "Jesús Nazareno y otro (...) Señor que sale en Domingo de Ramos" y "Crucifixo de Marfil con algunos reliquiarios". ${ }^{29}$ En la iglesia de la reducción de San Pedro, en el inventario se refieren "dos rollos de lienzos pintados de la pasión de Christo". ${ }^{30}$ En la misión de Santa Ana se mencionan a una imagen de "Nuestra Señora" y un "Cristo Cricifijado" ${ }^{31}$ y en la de Exaltación "Nuestra Señora que está en el Altar". ${ }^{32}$ La misión de los Santos Reyes poseía más imágenes. Se hizo relación de una "Virgen de los Dolores", ${ }^{33}$ "Nuestra Señora del Rosario", 34 "Dos Imágenes, la una de Nuestra Señora de la Concepción en otro [altar] colateral y otro de los Dolores en un Caxón, en la sacristía fuera de otra que se halla en el altar de Christo. Dos Id. la una pequeña que sale en los días del Rosario y otra de la Concepción con su vestido y adorno". ${ }^{35}$ En la misión de San Simón se menciona la figura escultórica de la "Virgen", ${ }^{36}$ en San Ramón "Dos Santos Christos", ${ }^{37}$ en San Joaquín "Un Santo Christo con su pie y flores de plata" ${ }^{38}$ y, finalmente, en la Purísima Concepción, una "Virgen" con "Tres Coronas de la Virgen, las dos maiores que la Otra, con algunas piedras falsas" y "Una lámina Romana de la Purísima Concepción". ${ }^{39}$

Las imágenes de Cristo y la Virgen fueron acompañadas con otras representaciones. En la reducción de los Reyes, además de las imágenes marianas, se menciona también una representación de "San Juan" y otros "Santos" ${ }^{40}$ En la

27 Eguiluz 2010 [1696]: 65.

28 Quintana 2005 [1756]: 154. Pedro Marban menciona que "los viernes se dice al alba la misa del Santo Cristo, en que se canta la Pasión del Señor"; MARban 2005 [1700]: 63.

${ }^{29}$ ABNB, M. y Ch., GRM, vol. 1, I, f. 18v.

${ }^{30}$ ABNB, M. y Ch., GRM, vol. 1, I, f. 27r.

${ }^{31}$ ABNB, M. y Ch., GRM, vol. 1, I, f. 36r.-37r.

${ }^{32}$ ABNB, M. y Ch, GRM, vol. 1, I, f. 41v.

${ }^{33}$ ABNB, M. y Ch., GRM, vol. 1, I, f. 46v.

${ }^{34}$ ABNB, M y Ch, GRM, vol. 1, I, f. 47r.

${ }^{35}$ ABNB, M. y Ch., GRM, vol. 1, I, f. 49r.-49v.

${ }^{36}$ ABNB, M. y Ch., GRM, vol. 1, III, f. 177r.

${ }^{37}$ ABNB, M. y Ch., GRM, vol. 1, III, f. 179v.

${ }^{38}$ ABNB, M. y Ch. GRM, vol.1, III, f. 184r.

39 ABNB, M. y Ch., GRM, vol. 1, III, f. 189 r.-192 r.

${ }^{40}$ ABNB, M. y Ch., GRM, vol. 1, I, f. 46r.-47r. 
misión de Santa María Magdalena se describen las figuras de "un Santo Christo pequeño de bronce con dos imágenes pequeñas" y una "Santa María Magdalena". ${ }^{41}$ En la reducción de San Nicolás de Bari, un "San Nicolás" y una "Santísima Virgen". ${ }^{42}$

Algunas reducciones contaban con una riqueza sorprendente de imágenes religiosas. Verbigracia, en el templo de la misión de los Santos Reyes:

en todo el cuerpo de la iglesia están repartidos ocho Lienzos de la Pasión de Nuestro Señor y mezclados entre ellos doce de los Apóstoles con sus respectivos marcos y otros doce de Nuestra Señora, fuera de otros dos en los colaterales que el uno comprehende la Resurrección, y el otro Despedimiento. Al pie de Nuestro Christo y su Altar un liencecito de Nuestra Señora con su marco dorado y en la sacristía doce lienzos de varios tamaños repartidos en ella (...) Quatro Santo Christo el uno de marfil grande (...) En el Arco del nicho de la Virgen siete laminitas Romanas. ${ }^{43}$

En la iglesia de la misión de San Ignacio fueron registradas las siguientes imágenes: "Un Crucifixo de marfil", "Variedad de efigies de escultura y entre ellas una Imagen del niño Jesús Napolitano y a una proporción sus respectivas andas", "la efigie de San Pedro Apóstol", "la efigie de María Santíssima Señora Nuestra", "efigie de Santa María Magdalena", "Nuestra Señora de los Dolores", "Jesús Nazareno". ${ }^{44}$ También numerosas imágenes se encontraron en el templo de la misión de San Francisco de Borja: "María Santíssima con el Nino Jesús", "un Jesús Dorado", "San Pedro", "Imagen Grande de Nuestra Señora”, "Cristo Señor Nuestro", "Nuestra Señora y San Juan", "San Pablo Apóstol", "Cinco Santos Christos de marfil". ${ }^{45}$

Las imágenes mencionadas en esta sección son comunes para toda la Iglesia católica de los siglos XVII y XVIII, teniendo predominancia las representaciones de Cristo y la Virgen, santos a menudo acordes con las advocaciones de las iglesias, y escenas varias provenientes de la biblia o de la tradición. Algunas de las advocaciones son típicas para la cultura española, tanto en la península como en los territorios americanos; por ejemplo, el "Jesús Nazareno"

${ }^{41}$ ABNB, M. y Ch., GRM, vol. 1, I, f. 53r.-53v.

${ }^{42}$ ABNB, M. y Ch., GRM, vol. 1, III, f. 163v.

${ }^{43}$ ABNB, M. y Ch., GRM, vol. 1, I, f. 49v.

${ }^{44}$ ABNB, M. y Ch., GRM, vol. 1, I, f. 58v.-60r.

${ }^{45}$ ABNB, M. y Ch., GRM, vol. 1, III, f. 166r.-168 r. En algunas descripciones faltan los nombres de las diferentes advocaciones de las esculturas. Por ejemplo, en la iglesia de la misión de San Pedro se mencionan "siete bultos todos vestidos con sus andas doradas grandes" [ABNB, M. y Ch., GRM, vol. 1, I, f. 25v.-26r.]. Sabemos que en esta misión fueron conservados los objetos (también las figuras escultóricas y otras imágenes) de la misión de San Joaquín y la Purísima Concepción para protegerlos durante el conflicto con los portugueses [ABNB, M. y Ch., GRM, vol. 1, III, f. 189v. y 192r.]. 
mencionado en las iglesias de las reducciones de San Ignacio y Francisco Javier.

La presencia de estas figuras tiene una íntima relación con el culto. Eguiluz menciona que durante la procesión del Viernes Santo se ponían "vestidos de Nazarenos, con Cruces a los hombros, cantando los Coros de Músicos de Miserere y Endechas tristes en su lengua de Pasión de nuestro Señor Jesucristo." ${ }^{46}$ Durante la época barroca, el culto del Nazareno floreció tanto en Europa como en América. Se establecieron un buen número de cofradías que se intitularon con el nombre de Jesús Nazareno y decoraron sus capillas con la imagen del Cristo de la pasión portando su cruz. ${ }^{47}$

\section{AdVOcaCiones JEsUitas}

Como hemos mencionado, el arte fue siempre muy importante para los miembros de la Compañía de Jesús. La iconografía particular de los jesuitas se transformó a partir de la canonización de San Ignacio de Loyola y San Francisco Javier en $1622,{ }^{48}$ los primeros santos de la orden (Fig. 7). Desde esta fecha, sus retratos enriquecieron la decoración de las iglesias en todo el orbe católico. Otros personajes representados en los templos jesuitas fueron Francisco de Borja, Luis Gonzaga y Estanislao Kostka. ${ }^{49}$ Llama la atención que la iconografía de los santos jesuitas se desarrolló, sobre todo, fuera de Roma, durante la segunda mitad del siglo XVII.

Las imágenes de los santos jesuitas se trasladaron rápidamente a tierras hispanas. Artistas como Juan de Valdés Leal, Francisco de Herrera, Francisco Zurbarán, Bartolomé Esteban Murillo y Alonso Cano dieron su aportación al desarrollo de la iconografía jesuítica en España y América. Igualmente, los grabados fueron importantes difusores de los modelos de representación de los santos jesuitas, ya que éstos servían como referentes para las composiciones

46 Eguiluz 2010 [1696]: 65.

${ }^{47}$ Llamazares Rodríguez 2010: 63. Para más información sobre las imágenes y el culto al Nazareno, véase también: SÁnchez López 2010: 111-186; Pleguezuelo 2010: 187-214; WIтко 2009: 167-193; Wiтко 2010.

${ }^{48}$ El primer impulso en la difusión de la iconografía jesuita, podemos demarcarlo con la fecha de beatificación de Ignacio de Loyola (1609) y la edición del libro con imágenes sobre su vida: Vita beati P. Ignatii Loiolae Societatis Iesu (Roma, 1609). Los grabados sirvieron para la elaboración de las primeras composiciones pictóricas sobre el santo; BAILEY 2009 [2003]: 19. El ciclo de grabados es anónimo. Probablemente, Rubens creó una o más tablas y fueron grabadas en el taller de Galle en Amberes; BAILEy 2003: 150. El libro contiene 79 grabados en cobre con las escenas más importantes de la hagiografía ignaciana PfeIfFer 2003: 182-184.

49 BAILEY 2003: 146. 
pictóricas. A su vez, la difusión de los libros ilustrados contribuyó considerablemente a dicha propagación de imágenes. Su presencia e importancia son visibles por toda Europa y América, a través de los libros resguardados en colecciones y bibliotecas. ${ }^{50}$ Por ejemplo, en ambos lados del Atlántico se conservan muchas series de la Vida ilustrada de San Ignacio, de la cual aparecieron diferentes versiones desde el momento de la beatificación ${ }^{51}$ de Ignacio hasta principios del siglo XVIII. ${ }^{52}$

A mediados del siglo XVIII, las representaciones de San Ignacio y San Francisco Javier se convirtieron en un elemento indispensable del programa visual de cada templo jesuita, ${ }^{53}$ a la par del incremento de popularidad de las imágenes de otros jesuitas. En las misiones de Mojos, en la mayoría de las iglesias encontramos los retratos de santos y beatos jesuitas, en conjunto con escenas de sus historias hagiográficas. Por ejemplo, en la misión de San Francisco Javier se menciona "una lámina de San Ignacio con adorno de plata" y una "Imagen de San Xavier". ${ }^{54}$ Asimismo, en la descripción de la iglesia del pueblo San Nicolás de Bari, aparece una referencia a "San Ignacio y San Xavier". ${ }^{55}$ En la iglesia de la reducción de los Santos Reyes se enlistan un "San Francisco Xavier", un "San Luis Gonzaga y San Francisco Regis". ${ }^{56}$ Y en la de Santa María Magdalena, "una lámina de San Francisco de Borja con su marco y piezas de plata sobredorada". ${ }^{57}$

La iconografía de las iglesias en San Ignacio y San Francisco de Borja fue más rica por las advocaciones particulares de sus templos y reducciones. En la misión de San Francisco de Borja se menciona "una lámina chapeada de plata que contiene una Reliquia de San Francisco de Borja", la imagen de "Nuestro Santo Padre Ignacio" y un ciclo narrativo con "Quarenta y quatro lienzos, y la Vida de San Francisco de Borja nueba". ${ }^{58}$ Finalmente, en la misión de San Ignacio, se registraron dos imágenes escultóricas: "un Ando de Nuestro Padre San Ignacio (...) un vestido entero para la efigie del expresado Nuestro Padre" y "la efigie de Nuestro Apóstol de las Indias San Francisco Xavier"; además de un ciclo pictórico con "Treinta lienzos apaisados de la vida de nuestro

\footnotetext{
${ }^{50}$ NAVAs GutiérReZ 1993: XLVII-XLIX.

51 Por encargo de sus compañeros, San Ignacio fue retratado justo después de su muerte por Jacopino del Conte (1510-1598). La imagen fue realizada a partir de su mascarilla mortuoria. Dicha obra fue reproducida en múltiples ocasiones; PFEIFFER 2003: 177.

52 Pfeiffer 2003: 190-196.

53 BAILEY 2003: 151-152.

${ }^{54}$ ABNB, M. y Ch., vol. 1, I, f. 18v.-19r.

${ }_{55}$ ABNB, M. y Ch., GRM, vol. 1, III, f. 174v.

${ }^{56}$ ABNB, M. y Ch, GRM, vol. 1, I, f. 46 r.

${ }^{57}$ ABNB, M. y Ch., GRM, vol. 1, I, f. 54r.

${ }^{58}$ ABNB, M. y Ch., GRM, vol. 1, III, f. 165r--169r.
} 
Padre san Ignacio". ${ }^{59}$ Esta tradición sigue funcionando. En la antigua reducción de San Ignacio de Mojos, en el altar mayor reconstruido en el siglo XX encontramos la figura de San Ignacio Loyola en un nicho central y dos escenas de su vida en los cuadros ubicados en las calles laterales. [fig. 5] Las composiciones fueron realizadas basándose en los diferentes modelos grabados [figs. 6-7]. Entre los objetos artísticos de esta antigua misión de San Ignacio de Mojos encontramos también una imagen de bajo relieve con representación de San Estanislao Kostka [fig. 8].

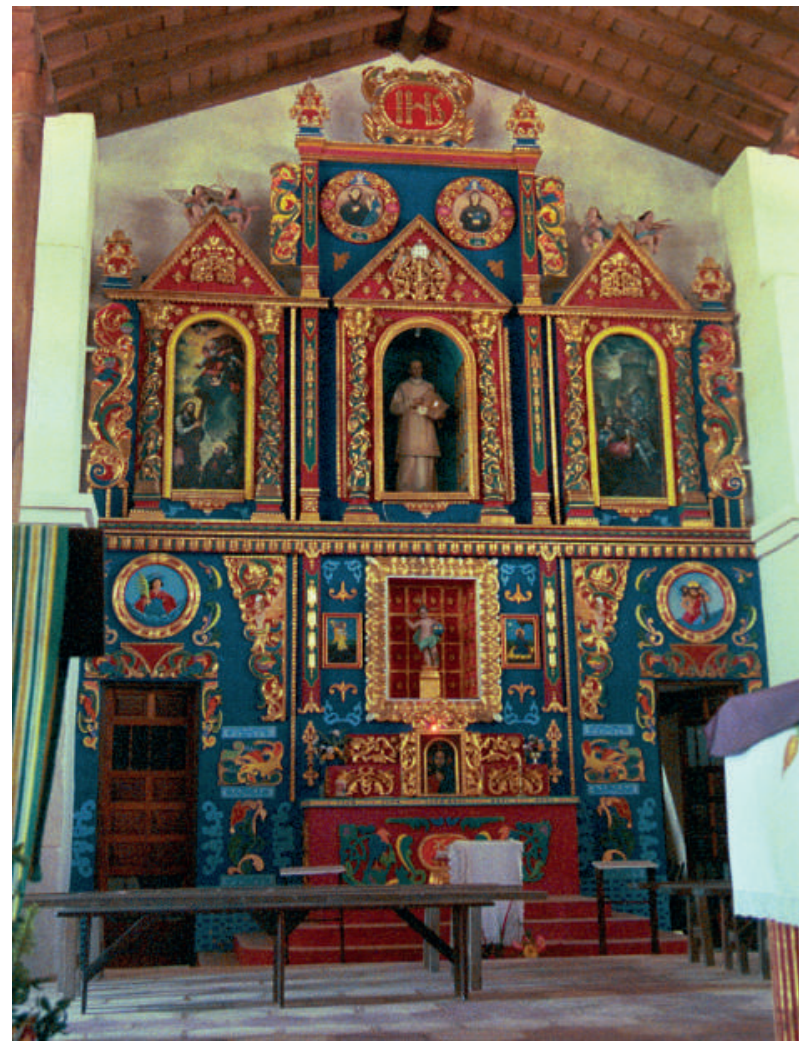

Fig. 5. Altar mayor con la figura de San Ignacio y escenas de su vida, anónimo, siglo XX, Iglesia San Ignacio de Mojos [fot. E. Kubiak 2004].

${ }^{59}$ ABNB, M. y Ch., GRM, vol. 1, I, f. 58v. -59 v. 

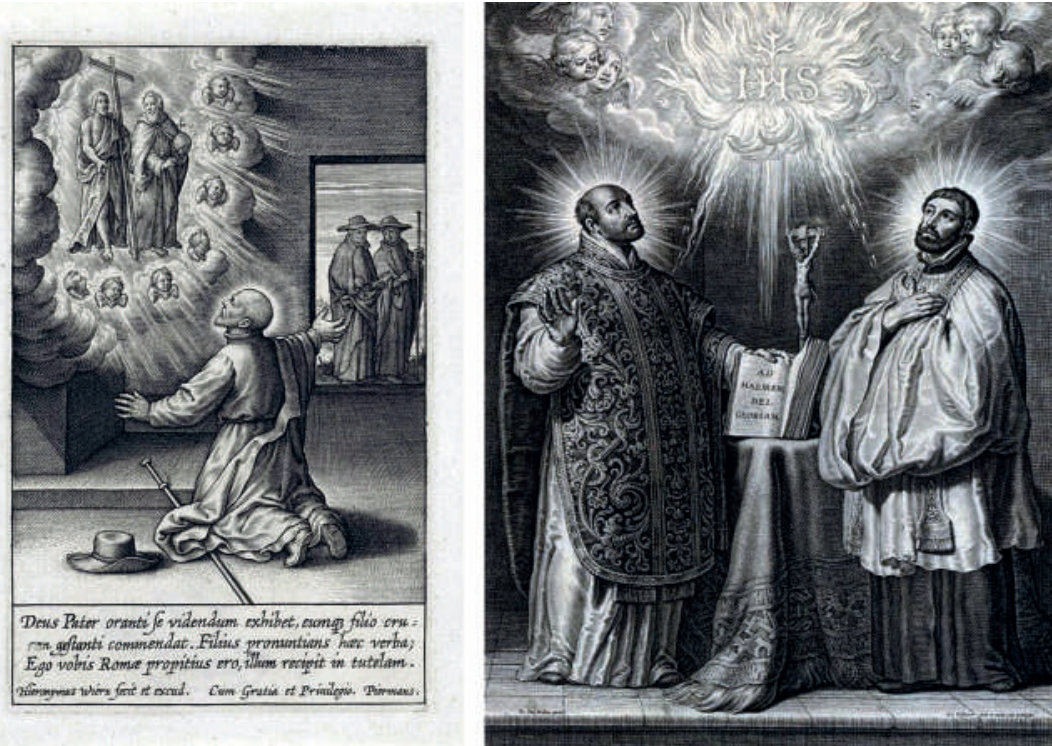

Fig. 6. La visión de Storta, 1611-1615, grabado en cobre, Hieronymus Wierix (ok. 1553-1619), grabado, Amsterdam, Rijksmuseum, Rijksprentenkabinet, Signatura: RPP-1898-A-19918; San Ignacio de Loyola y San Francisco Javier, grabado en cobre, 1622, Schelte Adamsz Bolswert (1586-1659) según Paul Rubens (1577-1640).
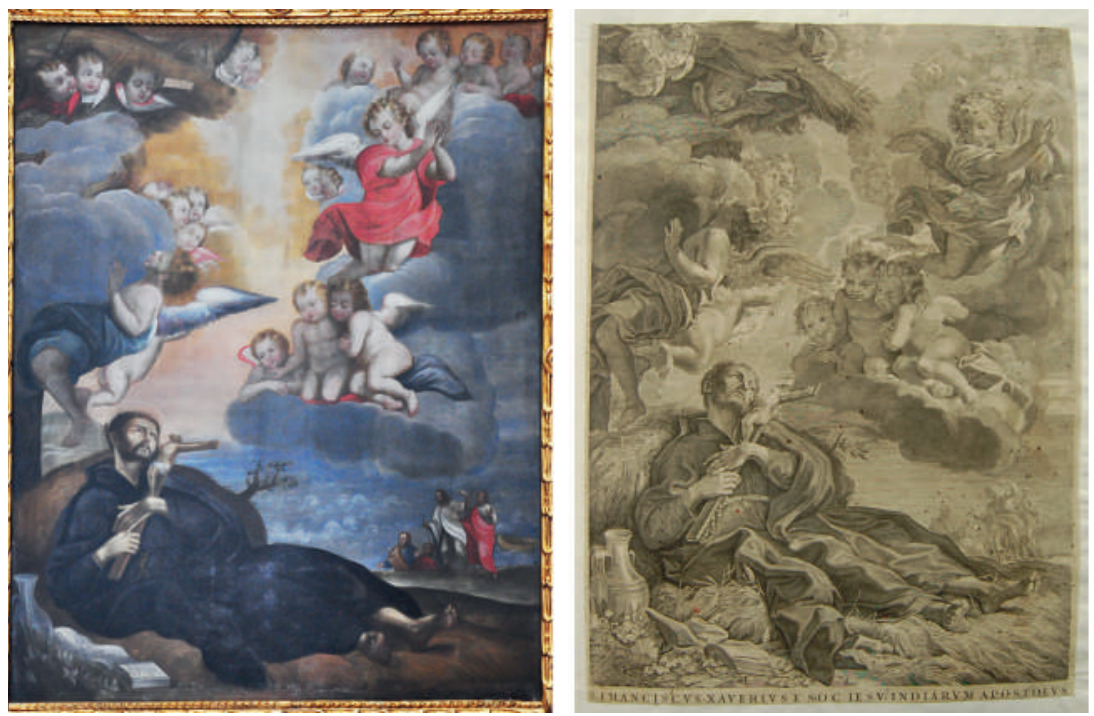

Fig.7. Muerte de San Francisco Javier, Benoît Farjat (1646-1720), grabado según el diseño de Giovanni Battista Gaulli (1639-1709), British Museum, Signatura: 1871,0429.446; Muerte de San Francisco Javier, anónimo, siglo XVIII, Convento de la Merced, Cusco [fot. E. Kubiak, 2018]. 
Fig. 8. San Estanislao Kostka, bajorrelieve policromado, anónimo, siglo XVIII(?), escultura en el museo parroquial de San Ignacio de Mojos [fot. E. Kubiak, 2004].

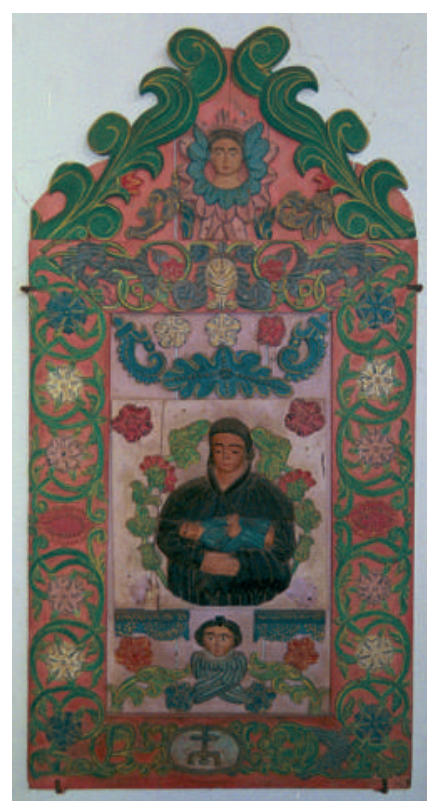

\section{AdVOCACIONES LOCALES}

La arraigada y larga tradición de las imágenes es muy importante para los católicos, puesto que su presencia constituye un símbolo de legitimidad y son consideradas como testimonio de una verdadera santidad. ${ }^{60}$ Incluso en la relación entre las representaciones nuevas y locales, se gestaron historias para subrayar la antigüedad de sus cultos y su relación con personajes históricos. ${ }^{61}$ Entre las advocaciones locales y típicas del Virreinato del Perú, distinguimos tres que hasta el día de hoy gozan de gran popularidad: el Señor de los Temblores, Nuestra Señora de Belén (cusqueña) y la Virgen de Cocharcas.

\section{Señor de los Temblores}

Hasta 1650, la figura de Jesucristo fue conocida por la común representación del Cristo Crucificado de la catedral cusqueña y no era muy popular. [fig. 9] Su éxito empezó con el terremoto devastador de 1650. La sociedad barroca interpretaba las catástrofes naturales como resultado de la ira divina, una

${ }^{60}$ Verbigracia, en Europa, los jesuitas adquirieron templos antiguos y decidieron mantener algunos objetos de la decoración. Especialmente conservaron algunas imágenes de culto, debido a su importancia en la vida religiosa de la sociedad local [GALEWSKi 2012: 43].

${ }^{61}$ JURKOWLANIEC 2008: 441. 
respuesta de Dios ante la inmoralidad humana. Por ello, el remedio ante la debacle fueron las oraciones y procesiones. Según la tradición, cuando la figura del Cristo salió de la catedral, el terremoto cesó. Desde este momento la efigie es conocida como el Señor de los Temblores. ${ }^{62}$ Las representaciones de dicho Cristo son parecidas a la escultura gótica del Cristo de Burgos que data del siglo XIV, la cual se venera en su capilla en la catedral burgalesa. ${ }^{63}$ [fig. 10] Según la leyenda, la escultura del Señor de los Temblores se realizó y envió a América por mandato de Carlos V. Si bien, dicha época no coincide con la datación de la escultura, ya que, según los conservadores, es posterior; su historia en conjunto con la descripción del viaje trasatlántico y sus acontecimientos milagrosos atribuidos, se afianzaron en la memoria colectiva de la sociedad cusqueña de la época colonial. Esta tradición se fortaleció con la crónica de Diego de Esquivel y Navia (1748), donde el autor reitera la información sobre el envío de la figura del Cristo Crucificado por Carlos V. Hoy, la mayoría de los investigadores considera que se trata de una creación local, posterior a 1560, adscrito al estilo de los talleres cusqueños, mostrando tanto la expresión de la forma como técnicas y materiales típicos de los Andes, utilizados para la realización de esculturas. ${ }^{64}$ Así, el Señor de los Temblores se convirtió en el patrono de la ciudad y, actualmente, su culto sigue siendo muy significativo. ${ }^{65}$ Cada Lunes Santo, la imagen del Cristo, decorado con flores rojas sagradas (ñucchu), sale a las calles de Cusco en una solemne procesión y cruza su camino acompañado por una multitud de fieles.

En la época virreinal, el Señor de los Temblores fue considerado como una advocación protectora frente a los terremotos, pero también frente a otras catástrofes naturales. El original servía como modelo para las representaciones escultóricas y pictóricas. Sus veras efigies reproducen no sólo la misma figura, sino también las partes de la capilla: candelarios, jarrones con flores y elementos de madera esculpida. En ocasiones, al Cristo Crucificado lo acompañan la Virgen Dolorosa y San Juan, y/o también los donantes. ${ }^{66}$ [figs. 11-14]

${ }^{62}$ O'Phelan Godoy 2013: 168.

${ }^{63}$ Valencia EsPinOZa 1990: 49-50.

${ }^{64}$ Stanfield-Mazzi 2013: 97-110; EsQuivel y Navia 1980 [1748]: 195.

${ }^{65}$ Durante la última restauración, realizada por un equipo interdisciplinario del Instituto Nacional de Cultura (2005), los investigadores encontraron dentro de la escultura, diversas cartas de los creyentes con oraciones, quejas y súplicas. Las más antiguas datan de la década de los sesenta del siglo XVIII y la última está fechada en el año de 1937; aunque también se encontraron cartas más actuales, evidentes por su caligrafía contemporánea. VEGA-CENTENo 2006: 9-43.

${ }^{66}$ Desde la Edad Media, los retratos aparecen en las composiciones religiosas en la representación de orantes que contemplan el suceso sacro. Esta costumbre pasó de Europa a la iconografía barroca en América. En las escenas religiosas se realizaron retratos de donantes tanto españoles y criollos, como mestizos e indios (caciques). GisBerT 2008 [1980]: 92. 


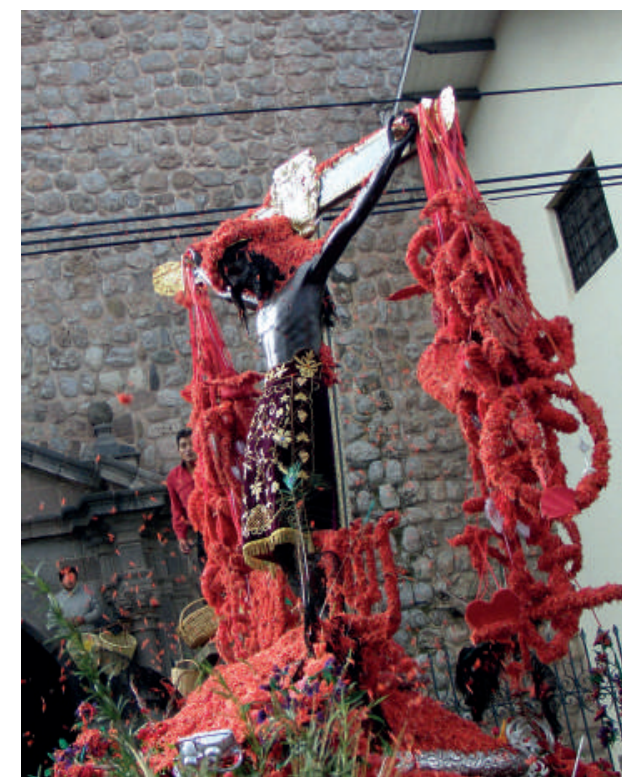

Fig. 9. Señor de los Temblores, figura de la catedral de Cusco, anónimo, siglo XVI, procesión durante El Lunes Santo 2010 Cusco (fot. E. Kubiak, 2010).

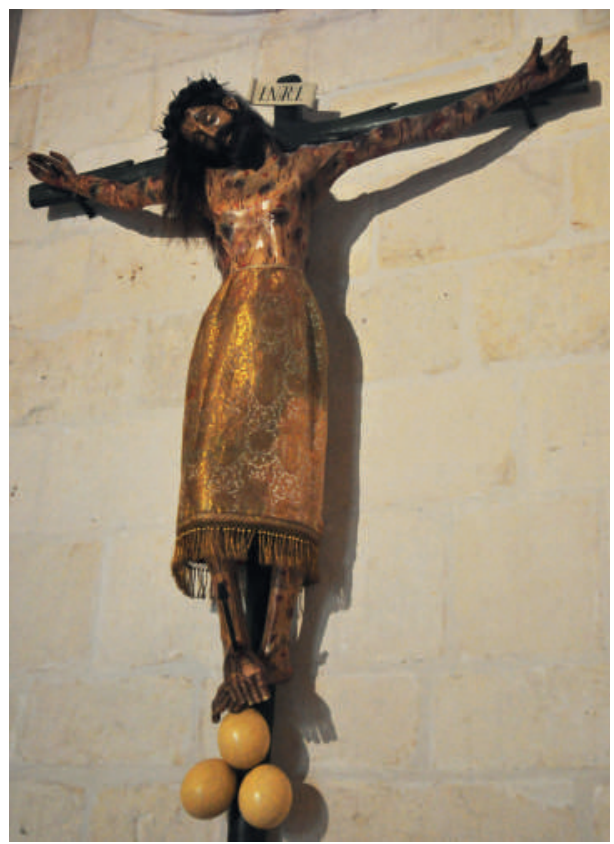

Fig. 10. Santo Cristo de Burgos, anónimo, siglo XIV, Capilla del Santísimo Cristo de Burgos de la Catedral de Burgos, España (fot. E. Kubiak, 2018). 


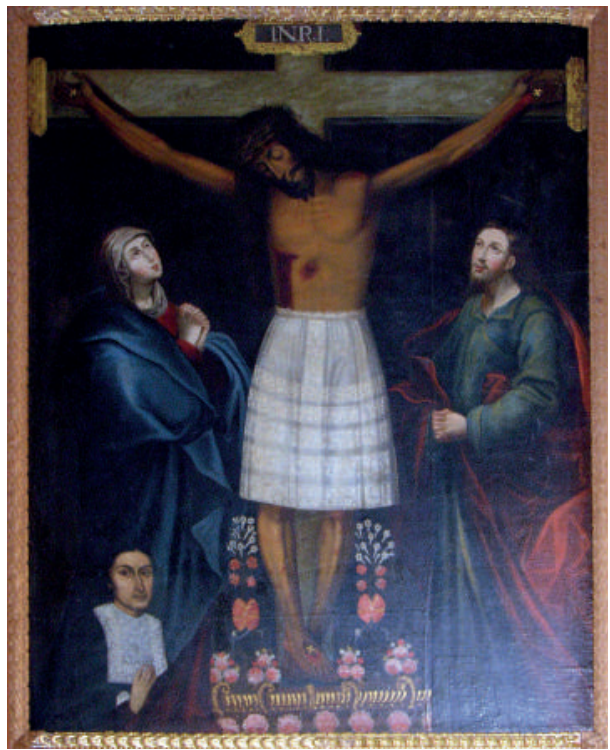

Fig. 11. Señor de los Temblores, anónimo, siglo XVIII, Ex-Beaterio de Las Nazarenas, Cusco (fot. E. Kubiak, 2015).

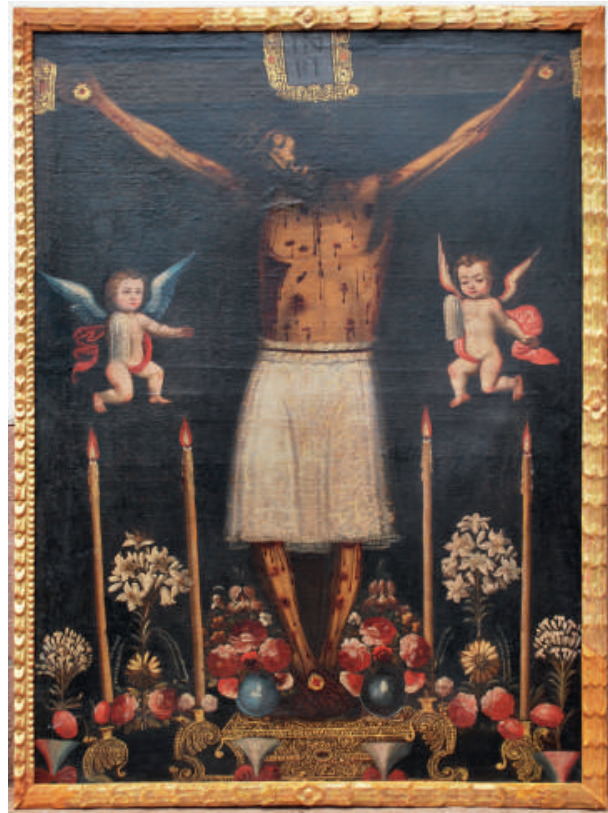

Fig. 12. Señor de los Temblores, anónimo, siglo XVIII, Iglesia de San Cristóbal, Cusco (fot. E. Kubiak, 2018). 


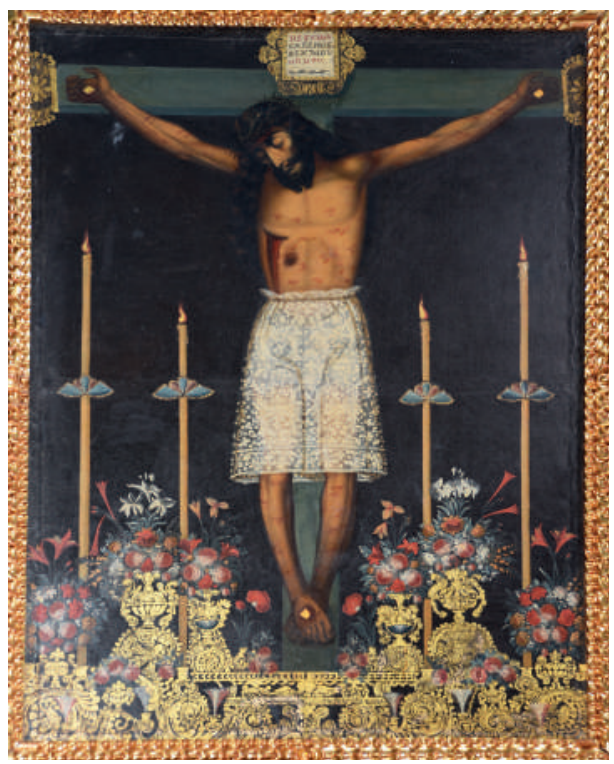

Fig. 13. Señor de los Temblores, anónimo, siglo XVIII, Sacristía de la Iglesia de la Compañía de Jesús, Cusco (fot. E. Kubiak, 2020).

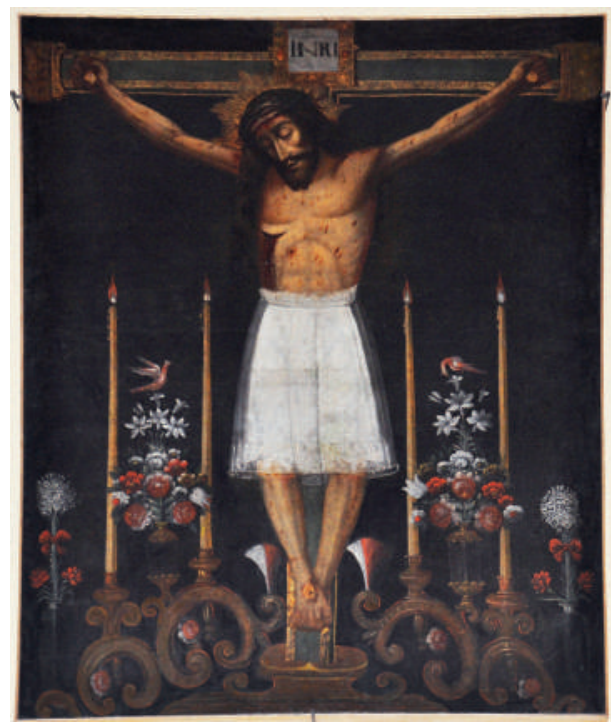

Fig. 14. Señor de los Temblores, anónimo, siglo XVIII, Ex-Beaterio de Santa Rosa, Cusco (fot. E. Kubiak, 2018). 
En dos iglesias de las misiones de la región de Mojos, se menciona la representación del Señor de los Temblores. En la reducción de los Reyes había "un Christo Grande nuevo que es copia del Señor de los Temblores del Cusco y dos que el uno está colocado en un colateral y otro en un cajón que existe en la sacristía". ${ }^{67}$ También en el templo de la misión de San Ignacio se menciona una "efigie del Señor de los Temblores" ${ }^{68}$ y como parte del tesoro "Tres clavos grandes de plata para el Santo Christo de los Temblores sacado por el original que se venera en la Santa Catedral del Cusco, acuia Ciudad embio el Señor emperador Don Carlos Quinto". ${ }^{69}$

\section{Nuestra Señora de Belén}

La Virgen de Belén es la patrona del Cusco, junto con el Señor de los Temblores. La imagen milagrosa se encuentra en la iglesia de Nuestra Señora de Belén. La efigie fue también mencionada por Diego de Esquivel y Navia (1748), en relación con la información sobre el envío de la escultura por Carlos V. ${ }^{70} \mathrm{Su}$ transportación también estuvo llena de acontecimientos milagrosos: después de una tormenta atroz cuando fue destruido el barco que la trasladaba, la ima-

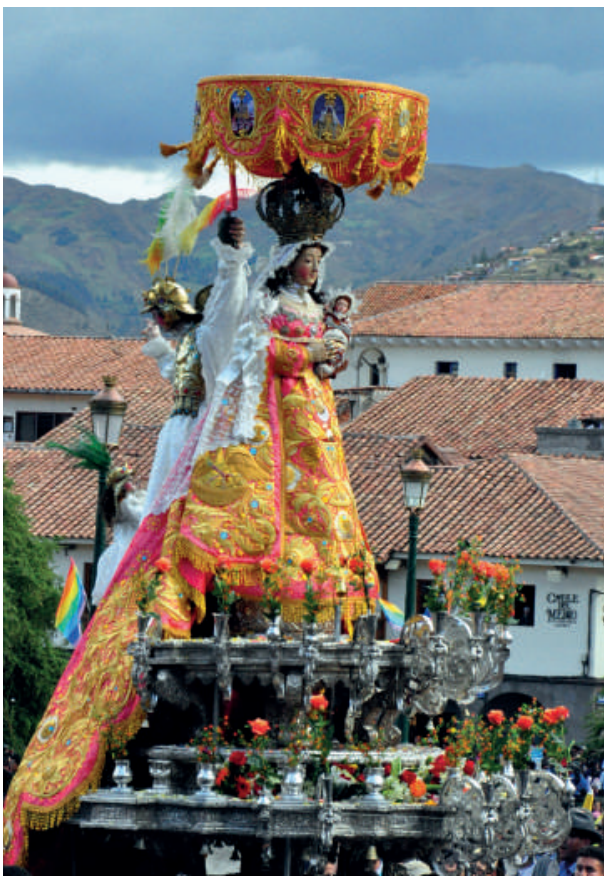
gen llegó a la costa peruana en un cajón que flotaba sobre las aguas. Fue encontrada por unos pescadores del puerto de San Miguel. Según la tradición la figura fue trasladada al Cusco desde el puerto del Callao en el año 1560. Desde ese momento, se convirtió en protectora de la ciudad, intercediendo milagrosamente ante pestes, sequías, terremotos y otras calamidades. La imagen encontró su lugar en la iglesia de los Santos Reyes que cambió su nombre por el de Nuestra Señora de Belén.

Fig. 15. Virgen de Belén, imagen milagrosa de la Virgen en la iglesia de Belén, Cusco, anónimo, siglo XVII, procesión de Corpus Cristi 2013 (fot. E. Kubiak 2013).

${ }^{67}$ ABNB, M. y Ch., GRM, vol. 1, I, f. 4 r.

${ }^{68}$ ABNB, M. y Ch., vol. 1, I, f. 60v.

${ }^{69}$ ABNB, M. y Ch., vol. 1, I, f. 58r.

${ }^{70}$ EsQuivel y Navia 1980 [1748]: 195. 
La figura escultórica es de tamaño natural. La Virgen sostiene al Niño Jesús con ambos brazos. [fig. 15] Su vestuario es muy fastuoso, adornado con muchas alhajas. La popularidad de la imagen determinó la creación de su iconografía pictórica y la consecuente producción vera efigies. El lienzo más famoso de este tipo fue creado con una orden del obispo Manuel Mollinedo y Angulo y se encuentra en la catedral del Cusco. ${ }^{71}$ [fig. 16] El autor de la obra, Basilio de Santa Cruz Pumacallao, pintó la figura de la Virgen de Belén en su retablo, con el donante del lienzo arrodillado con su escudo en la mesa del altar. En el fondo de la composición se encuentran la historia del viaje de la imagen y algunos milagros concedidos por ella. Otras representaciones pictóricas son más simples. A menudo aparece sólo la figura de la Virgen con el Niño, vestida con un traje de forma triangular, ricamente decorada con flores y perlas [fig. 17].

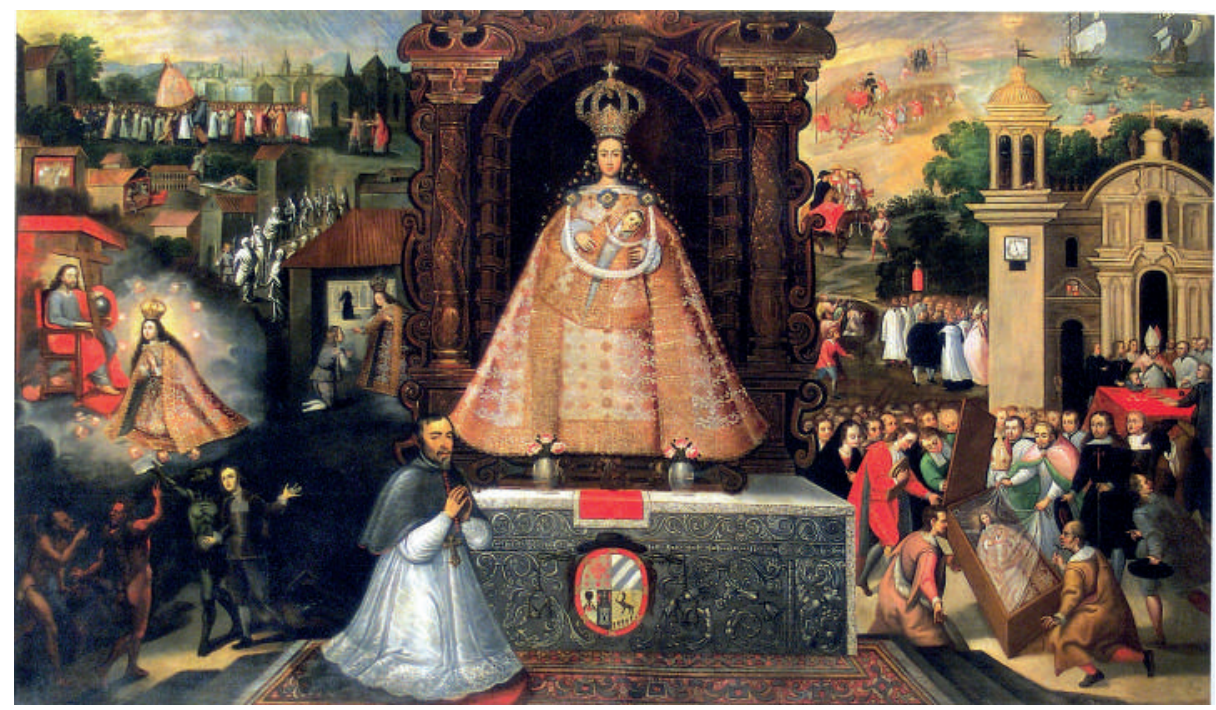

Fig. 16. Basilio de Santa Cruz Pumacallao, Virgen de Belén con el obispo Manuel de Mollinedo y Angulo como donante (1693-1698), Catedral de Cusco, Perú (fot. E. Kubiak 2015).

71 SCHENONE 2008: 311-312. 


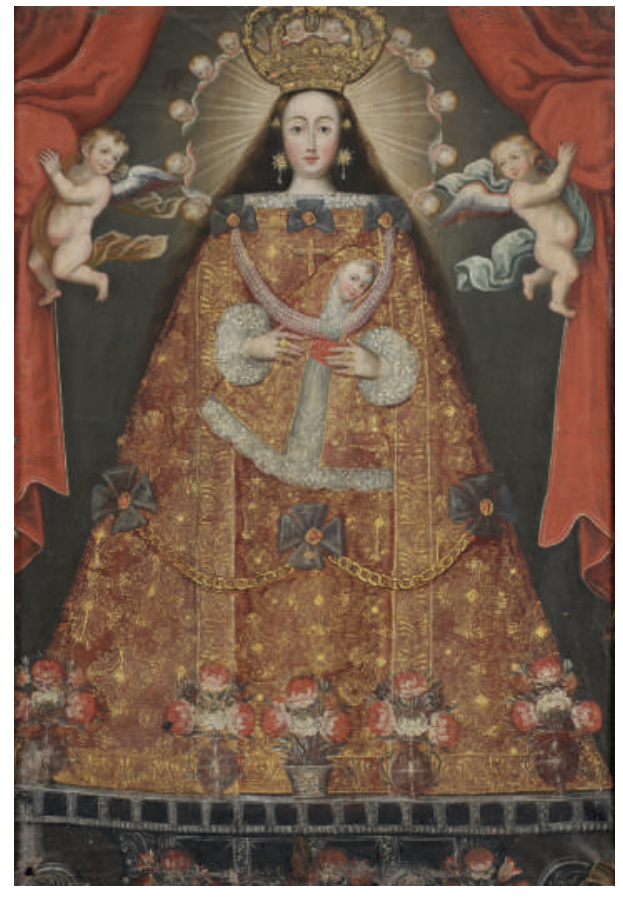

En las misiones de Mojos se menciona solamente una vez la imagen de la Virgen de Belén, en la iglesia de la reducción de Trinidad: "un lienzo hecho en Cusco de Nuestra Señora de Belén en cajoncito adornado". ${ }^{72}$

Fig. 17. Virgen de Belén, anónimo, siglo XVIII, Museo de Arte Religioso (Palacio Arzobispal), [fot. E. Kubiak, 2020].

\section{Virgen de Cocharcas}

La Virgen de Cocharcas es una de las advocaciones propias de la región andina del Perú. La imagen original se encuentra en un pueblo llamado Cocharcas, localizado en la provincia de Andahuaylas, entre Cusco y Ayacucho. Podemos datar su culto a principios del siglo XVII y su auge a mediados del siglo XVIII. La figura de la Virgen de Cocharcas ${ }^{73}$ es una copia de la famosa escultura de la Virgen de la Candelaria de Copacabana (Bolivia), pero fue recibida por la sociedad local como propia después de los milagros concedidos; por ende, sus devotos le cambiaron el nombre de Copacabana por el de Cocharcas. La historia de la transportación de la escultura está relacionada con el indio Sebastián Quimichi, nacido en San Pedro de Cocharcas, quien sufrió una enfermedad y fue sanado gracias a la ayuda de la Virgen. La travesía desde Copacabana hasta Cocharcas fue muy larga y llena de vicisitudes. Según la tradición, el autor de la escultura cocharqueña fue el mismo Tito Yupanqui, el artista indio quien hizo también la figura de la Virgen de Copacabana. La fiesta de la Virgen

\footnotetext{
${ }^{72}$ ABNB, M. y Ch., GRM, vol. 1, I, f. 8v.

${ }^{73}$ Probablemente, la imagen fue realizada en maguey, material típico para los talleres coloniales en la región de Copacabana; SCHENONE 2008: 353.
} 
de Cocharcas se celebra el 8 de septiembre. ${ }^{74}$ Sus representaciones fueron mayormente difundidas en versiones pictóricas, donde se desarrolló una iconografía particular, curiosa y original. ${ }^{75}$ [figs. 18-21] Los lienzos de Nuestra Señora de Cocharcas representan a la Virgen con el Niño Jesús sobre unas andas y un aderezado baldaquín cubriéndola. En el fondo de la representación central se encuentra un paisaje campirano con edificios, montes, caminos y árboles que crean marcos para las numerosas escenas relacionadas con la vida cotidiana del pueblo y el culto a la Virgen; tal y como lo describe Héctor Schenone:

Por los caminos van los peregrinos con sus ponchos a rayas, que en algunos casos son atacados por los demonios, que quieren impedirles la llegada al santuario, y hasta les hacen zancadillas para que caigan en los precipicios. Otros han levantado carpas, muchos oran de rodillas mientras las mujeres, con sus trajes típicos, hacen la comida. Hacia el lado derecho está la iglesia con su perfil y la fuente donde la multitud de romeros acuden por agua, y en esa parte del cuadro se ven los frailes de las diversas órdenes confesando, bendiciendo o en cordial conversación. ${ }^{76}$

Fig. 18. Virgen de Cocharcas, anónimo, 1767, colección particular, Lima [DAMIÁN 1995: 59].

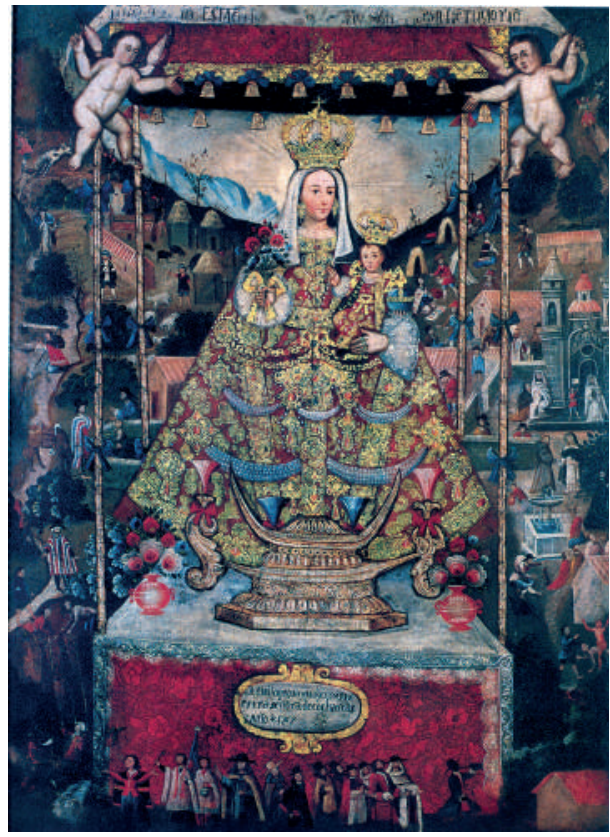

\footnotetext{
${ }^{74}$ Nuestra Señora de Cocharcas 2004: 86; SCHENONe 2008: 351-353, StANFIELD-MAZZi 2013: 77.

75 AlCalá 2011: 241. El amplio estudio sobre la Virgen de Cocharcas véase: ANGEL 2009: 299-339.

76 SCHENONE 2008: 353.
} 


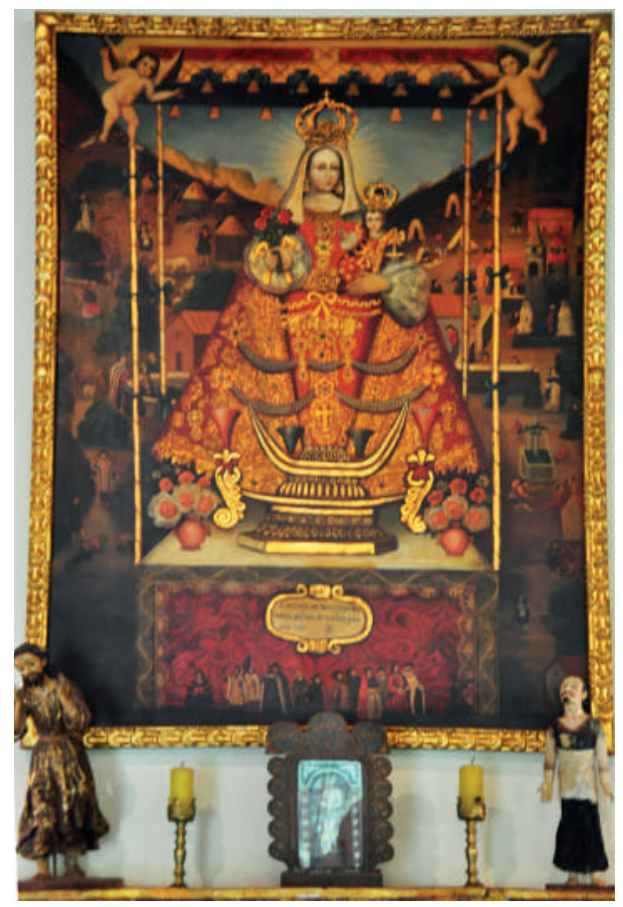

Fig. 19. Virgen de Cocharcas, anónimo, siglo XVIII, colección particular, [fot. E. Kubiak 2018].

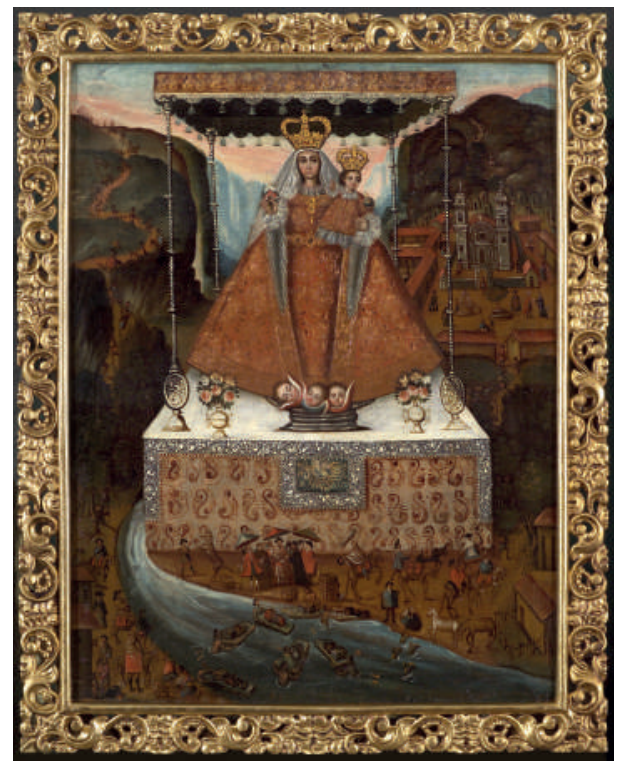

Fig. 20. Virgen de Cocharcas, anónimo, siglo XVIII, colección Barbosa-Stern, [fot. E. Kubiak 2019]. 
Fig. 21. Virgen de Cocharcas, anónimo, siglo XVIII, colección particular, [Alcalá 2011: 242].

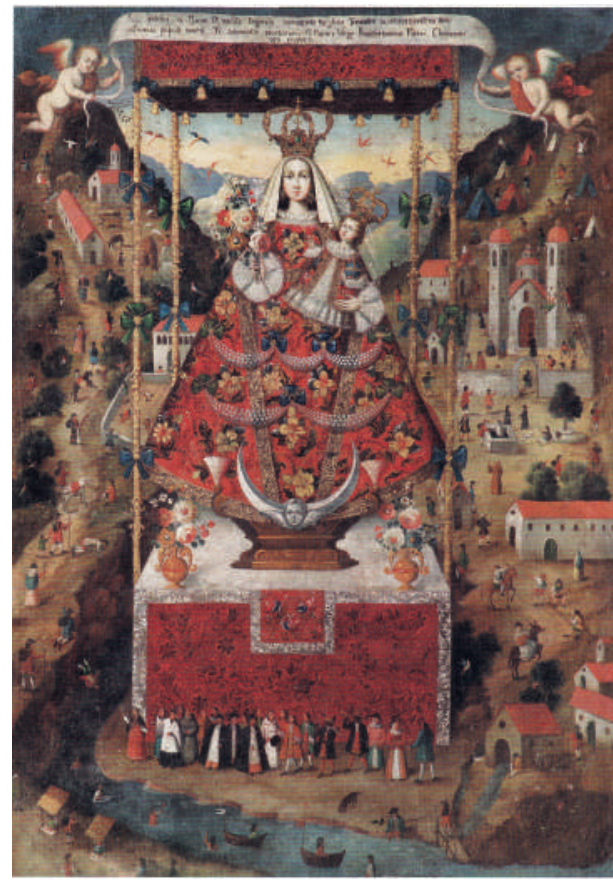

Con el tiempo la iconografía de la Virgen de Cocharcas cambió y se conocen las composiciones más simples. [fig. 22] En la tabla pintada del siglo XIX en la colección de Barbosa-Stern observamos solamente la imagen de "Nuestra Señora de Cocharcas" (de que nos informa la inscripción en el cuadro) en un pedestal hexagonal colocado en un altar. La Virgen carga al Niño Jesús en la mano izquierda y en la derecha agarra un ramo de flores. En la parte inferior de la composición las escenas de la vida cotidiana de los indígenas están reducidas a dos personajes. En la tabla tenemos dos figuras agregadas. Son las representaciones de dos orantes en las rodillas en forma de exvotos. El culto de la Virgen de Cocharcas mantuvo su intensa popularidad en todo el siglo XIX. ${ }^{77}$

En las misiones de Mojos, en la iglesia del pueblo San Pedro, los padres jesuitas decidieron dedicarle a la Virgen de Cocharcas una capilla. Por desgracia, el inventario no ofrece la descripción de la imagen, por lo tanto, no sabemos si fue una reproducción escultórica o pictórica. Solamente se refieren a la decoración y objetos de la "capilla de la Virgen de Cocharcas". ${ }^{78}$ A su vez, informa que había "treinta y seis candilejas de plata las seis de firma [están] en la capilla de la Virgen de Cocharcas"; igualmente, en la descripción de lámparas al interior

\footnotetext{
77 MariazZa Foy 2008: 138-139.

${ }^{78}$ ABNB, My Ch, Vol 1, I, f. 25 v.
} 


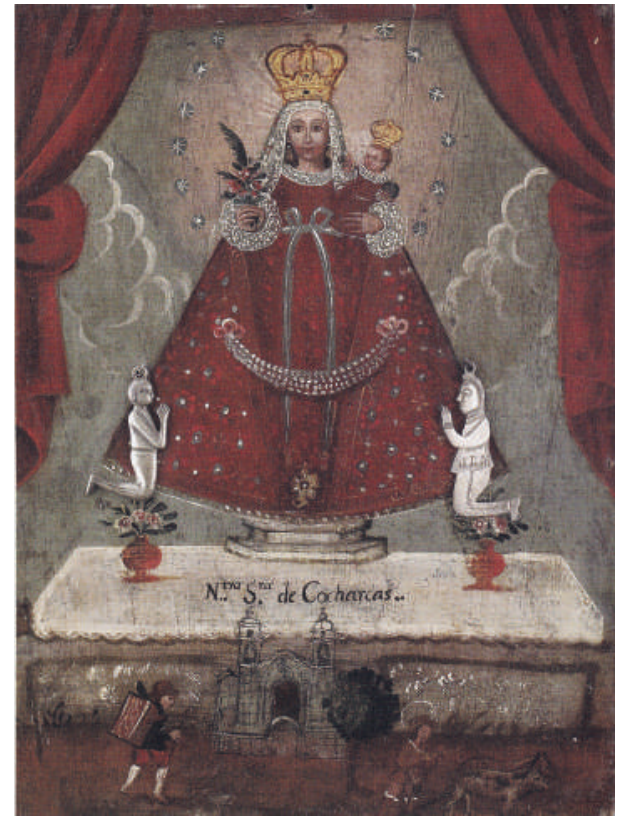

de la iglesia, se mencionó "la otra menor en la capilla de Cocharcas". ${ }^{79}$ Así, los padres jesuitas proporcionaron instalaciones adecuadas para el desarrollo de la devoción, fundando la capilla bajo esta advocación, permitiendo la permanencia de la decoración y objetos de culto de la imagen.

Fig. 22. Nuestra Señora de Cocharcas, anónimo, siglo XIX, colección Barbosa-Stern, [fot. E. Kubiak 2019].

\section{Conclusiones}

La mayoría de la producción artística jesuita, podemos destacarla como universal. Durante el proceso de evangelización, los referentes más importantes fueron las representaciones de la Virgen ${ }^{80}$, Cristo y los santos. Aparecieron también las escenas narrativas con las cuales los jesuitas respaldaban sus enseñanzas. Otro grupo de imágenes lo constituyeron las obras relacionadas con la orden religiosa, hecho evidente en el contexto de la decoración de las iglesias pertenecientes a la Compañía de Jesús. Ambos grupos podemos adscribirlos fácilmente a la tradición del mundo católico de la época. Sin embargo, lo que resulta más interesante es la elección de las advocaciones regionales. Nos preguntamos por qué los jesuitas decidieron introducir cultos locales cusqueños en territorios tan lejanos como las misiones de Mojos. Podemos aventurar algunas razones al respecto.

79 ABNB, My Ch, Vol 1, I, f. 24 r - 24 v.

${ }^{80}$ Sobre la devoción de la Virgen en América del Sur, véase también: GISBERT 2003: 61-97; Acosta Luna 2011; Schenone 2008. 
Sin duda, las advocaciones populares en Cusco gozaron de bastante popularidad en todo el Virreinato. Aunque la "concentración" de las imágenes se focalizó en la "capital andina", sus representaciones vinculadas con los cultos locales le dieron cabida en otras ciudades del Altiplano; de ahí que, especialmente, el Señor de los Temblores gozara de enorme aceptación. Por ejemplo, en las zonas sísmicas, su apoyo milagroso fue determinante en momentos críticos.

Hay que mencionar también que, durante esa época, Cusco funcionaba como un centro artístico. Hasta el día de hoy podemos encontrar pintura cusqueña en iglesias y museos de diferentes ciudades del Perú, Bolivia, Argentina, Chile y Ecuador. No sorprende entonces que en las misiones de Mojos también podamos localizar obras del arte del Cusco. Los cuadros cusqueños son mencionados tanto en los inventarios como en los relatos sobre las imágenes. Eguíluz informa que en la iglesia de San José se encontraban "en dos capillas unos lienzos de pintura primorosa del Cuzco". ${ }^{81}$ Así, el autor no sólo menciona los lienzos sino, a su vez, valora su alto nivel artístico.

Finalmente, podemos destacar un papel de consolidación de las tierras lejanas con los centros del virreinato a través del imaginario y también la construcción de la propia identidad dentro de la sociedad mestiza e india. Las imágenes locales fueron consideradas como típicas para la región, propias de la sociedad del Cusco. Podemos notar que, entre las advocaciones más populares y elegidas por los nobles incas del Cusco en la época colonial - destacadas por Scarlett O'Phelan Godoy-, ${ }^{82}$ fueron exactamente las mismas imágenes que encontramos en las misiones de Mojos. Parece posible que los jesuitas eligieron no sólo las imágenes más populares, sino también las más familiares para la sociedad indígena, tratando de aprovechar la tradición local en la construcción de la identidad de una nueva sociedad católica con los indios cristianos en las misiones de Mojos.

\section{BibLiOgRAFÍA}

\section{Documentos manuscritos}

ABNB, M. y Ch., GRM, vol. 1, I. - Archivo y Biblioteca Nacionales de Bolivia (Bolivia, Sucre), Fondo Mojos y Chiquitos, Colección Gabriel René-Moreno. 1, I, Inventarios de los bienes, así de Iglesia como Temporalidad, sucuestrados en los pueblos de Loreto, Trinidad, San Javier, San Pedro, Santa Ana, Exaltación, Magdalena, San Ignacio y

${ }^{81}$ Eguiluz 2010 [1696]: 50.

82 O’Phelan Godoy 2013: 157-209. 
Reyes desde del 4 de Octubre hasta el 16 de Diciembre de 1767 y son extendidos por los comisarios que para el efecto destacó el jefe de extrañamiento de Mojos Don Antonio Aymerich y formalizados por este en Loreto.

ABNB, M. y Ch., GRM, vol. 1, III - Archivo y Biblioteca Nacionales de Bolivia (Bolivia, Sucre), Fondo Mojos y Chiquitos, Colección Gabriel René-Moreno. 1, III, Inventarios de los bienes, pertenecientes a la iglesia y a comunidad de los pueblos de San Borja, San Nicolás, San Simón, San Martín, San Joaquín, y la Concepción extendidos y formalizados, el año de 1768 por los párrocos respectivos o por los comisarios de jefe de extrañamiento en Mojos y corren en el cuerpo de Auto Generales.

ABNB, M. y Ch., GRM, vol. 24, II - Archivo y Biblioteca Nacionales de Bolivia (Bolivia, Sucre), Fondo Mojos y Chiquitos, Colección Gabriel René-Moreno. 24, II, Relación informativa sobre el estado y modo de ser general de las misiones de Chiquitos, y sobre arreglos para ellas consultados con vista de su ulterior gobierno y administración temporal y espiritual. Por el Itmo. Sr. Obispo dr D. Francisco Ramón de Herboso.

\section{Fuentes primarias}

Aller 2005 [1669] - Julián de Aller, Relación que el Padre Julián de Aller [...], en: Josep M. Barnadas, Manuel Plaza (eds.), Mojos. Seis relaciones jesuíticas 1670-1763, Cochabamba, Historia Boliviana, 2005 [1669], pp. 25-39.

Altamirano 2005 [1713] - Diego Francisco de Altamirano, Breve noticia del estado en que se hallan el año de 1713 las misiones de infieles que tiene a su cargo la Provincia del Perú, de la Compañía de Jesús en las Provincias de Mojos, en: Josep M. Barnadas, Manuel Plaza (eds.) Mojos. Seis relaciones jesuíticas 1670-1763, Cochabamba, Historia Boliviana, 2005 [1713], pp. 67-76.

Bravo 1894 - Carlos Bravo, La Patria Boliviano. Estado Geográfico por Carlos Bravo con la colaboración de don Manuel V. Ballivian, La Paz, Imprenta de „La Paz”, 1894.

DSP 2007 - Dokumenty Soborów Powszechnych. Tekst taciński, polski, vol.

IV/2, Lateran V, Trydent, Watykan I, (eds.) Arkadiusz Baron y Henryk Pietras, Kraków, Wydawnictwo WAM, Księża Jezuici, 2007.

EDER 1985 [1772] - Francisco J. Eder, Breve descripción de las reducciones de Mojos ca. 1772. Trad. y ed. Joseph M. Barnadas, Cochabamba, Historia Boliviana, 1985 [1772]. 
EguILuz 2010 [1696] - Diego de Eguiluz, Relación de la misión apostólica de Mojos [1696]. Ed. Josep M. Barnadas, Cochabamba, Historia Boliviana, 2010 [1696].

EsQuival y NAVIA 1980 [1748] - Diego de Esquivel y Navia, Noticias cronológicas de la gran ciudad del Cusco, Félix Denegri Luna, Horacio Villanueva Urteaga y César Gutiérrez Muñoz (eds.), vol. I, Fundación Augusto N. Wiese, Banco Wiese. Lima.

Marban 2005 [1700] - Pedro Marban, Breve noticia de las misiones de infieles que tiene la Compañía de Jesús de esta Provincia del Perú en las Provincias de los Mojos, en: Josep M. Barnadas, Manuel Plaza (eds.) Mojos. Seis relaciones jesuíticas 1670-1763, Cochabamba, Historia Boliviana, 2005 [1700], pp.53-66.

Quintana 2005 [1756] - Alberto de Quintana, Carta-descripción a su hermano José de Quintana SJ sobre el viaje a Mojos y la misión de Mojos, en: Josep M. Barnadas, Manuel Plaza (eds.) Mojos. Seis relaciones jesuíticas 1670-1763, Cochabamba, Historia Boliviana, 2005 [1756], pp. 135-159.

Veneración 2012 [1563] - La veneración de los santos y el respeto a las imágenes en el Concilio de Trento (1563), en: Hans Belting, Imagen y culto. Una historia de la imagen anterior a la era del arte, trad. Cristina Diez Pampliega y Jesús Espino Nuño, Madrid, Akal, 2012, pp. 721-722.

\section{Libros y artículos}

Acosta Luna 2013 - Olga Isabel Acosta Luna, Milagrosas imágenes marianas en el Nuevo Reino de Granada, Madrid, Frankfurt am Main, Iberoamericana/ Vervuert, 2013.

AlcalÁ 2011 - Luisa Elena Alcalá, The image of the Devout Indian: the Codification of Colonial Idea, en: Ilona Latzew (ed.) Contested Visions in the Spanish Colonial World, Los Angeles, Los Angeles County Museum of Art, Yale University Press, 2011, pp.226-249.

Angel 2009 - Emily A. Angel, Visualizing a Colonial Peruvian Community in the Eighteenth-Century Painting of Our Lady of Cocharcas, "Religion and the Arts", 3 (13) (2009), pp. 299-339.

BAILEY 2003 - Gauvin Alexander Bailey, La contribución de los jesuitas a la pintura italiana y su influjo en Europa, 1540-1773, en: Giovanni Sale (ed.) Ignacio y el arte de los jesuitas, Milán, Ediciones Mensajero. Editorial Jaca Book, 2003, pp. 123-168. 
BAILEY 2009 [2003] - Gauvin Alexander Bailey, Between Renaissance and Baroque. Jesuit Art in Rome 1565-1610, University of Toronto Press. Toronto, Buffalo, London, 2009 [2003].

BAPTISTA 2001 - Javier Baptista, Expulsión de Hispanoamérica y Filipinas (1767-1770), en: Charles E. O’Neill, Joaquín María Domínguez (eds.) Diccionario Histórico de la Compañía de Jesús, vol. II. RomaMadrid, Institutum Historicum, Universidad Pontificia Comillas, 2001, pp. 1353-1359.

Baumgarten 2004 - Jens Baumgarten, Konfession, Bild und Macht. Visualisierung als katholisches Herrschafts - und Disziplinierung Konzept in Rom und habsburgischen Schlesien (1560-1740), Hamburg München, Dölling und Galitz Verlag, 2004.

Becerra Casanovas 1984 - Rogers Becerra Casanova, Retablos coloniales del Beni, Trinidad, sin editorial, 1984.

BeltiNg 2012 [1990] - Hans Belting, Imagen y culto. Una historia de la imagen anterior a la era del arte, trad. Cristina Diez Pampliega y Jesús Espino Nuño, Madrid, Akal, 2012 [1990].

Burrieza SÁnchez 2004 - Javier Burrieza Sánchez, Los misioneros en la Monarquía, en: Teófanes Egido (ed.) Los jesuitas en España y en el mundo hispánico, Madrid, Fundación Carolina, Centro de Estudios Hispánicos e Iberoamericanos, 2004, pp. 193-218.

Damián 1995 - Carol Damián, The Virgin of the Andes. Art and Ritual in Colonial Cuzco, Miami Beach, Grassfield Press, 1995.

GALEWSKi 2012 - Dariusz Galewski, Juzuici wobec tradycji średniowiecznej. Barokizacja kościołów w Kłodzku, Świdnicy, Jeleniej Górze i Żaganiu, Kraków, Universitas, 2012.

GISBERT 2008 [1989] - Teresa Gisbert, Iconografía y mitos indigenas en el arte,

La Paz, Editorial Gisbert y Cia., 2008 [1989].

Gisbert 2003 - Teresa Gisbert, Del Cusco a Potosí. La Religiosidad del Sur Andino, en: Ramón Mujica Pinilla (ed.) El Barroco Peruano 2, Lima, Banco de Crédito, 2003, pp. 61-97.

GonzÁlez García 2015 - Juan Luis González García, Imágenes sagradas y predicación visual en el siglo de oro, Madrid, Akal, 2015.

González SÁnchez 2017 - Carlos Alberto González Sánchez, El espíritu de la imagen. Arte y religión en el mundo hispánico de la Contrarreforma, Madrid, Catedra, 2017.

JuRADO DE GuERRA 2003 - Guissela Jurado de Guerra, Visión general sobre la expulsión de los jesuitas decretada por el Rey Carlos III, en: Jorge Salvador Lara (ed.) Historia de la iglesia católica en el Ecuador, 
vol. III. La iglesia en Quito en el Siglo XVIII, Quito, Ediciones Abya-Yala, 2003, pp. 1551-1558.

JURKowlANIEC 2008 - Grażyna Jurkowlaniec, Epoka nowożytna wobec średniowiecza. Pamiątki przeszłości, cudowne wizerunki, dzieła sztuki, Wrocław, Fundacja na Rzecz Nauki Polskiej, 2008.

KraSnY 2010 - Piotr Krasny, Visibilia signa ad pietatem excitantes. Teoria sztuki sakralnej $w$ pismach pisarzy kościelnych epoki nowożytnej, Kraków, Universitas, 2010.

KraSnY 2016 - Piotr Krasny, Figury obecności i nieobecności. Wprowadzenie do francuskiej dysputy o świętych obrazach i o roli sztuki $w \dot{z} y c i u$ Kościoła w epoce nowożytnej, Kraków, Universitas, 2016.

LlamaZARes Rodríguez 2010 - Fernando Llamazares Rodríguez, El «Nazareno» en la escultura barroca castellana, en: Pedro Miguel Ibáñez, Carlos Julián Martínez Soria (eds.) La imagen devocional barroca, Cuenca, Ediciones de la Universidad de castilla-La Mancha, 2010, pp. 63-109.

Mariazza Foy 2008 - Jaime Mariazza Foy, Nuestra Señora de Cocharcas, en: José Torres Della Pina (ed.) Mestizo del renacimiento al barroco andino, Lima, Impulso Empresa de Servicio SAC, 2008, pp. 138-139.

Mesa, Gisbert 2002 - José de Mesa y Teresa Gisbert, Monumentos de Bolivia, La Paz, Editorial Gisbert, 2002.

Mesa Gisbert, Mesa, Gisbert 2012 - Carlos D. Mesa Gisbert, José de Mesa y Teresa Gisbert, Historia de Bolivia, octava edición actualizada y aumentada, La Paz, Editorial Gisbert y Cia S.A., 2012.

Mujica Pinilla 2002 - Ramón Mujica Pinilla, El arte y los sermones, en: Ramón Mujica Pinilla (ed.) El Barroco Peruano, Lima, Banco de Credito, 2002, pp. 219-313.

Mujica Pinilla 2006 - Ramón Mujica Pinilla, "Reading without a Book" On Sermons, Figurative Art, and Visual Culture in the Viceroyalty of Peru, en: Suzanne Stratton-Pruitt (ed.), The Virgin, Saints and Angels. South American Painting 1600 - 1825 from the Thoma Collection, Stanford, California, Ed. Skira, 2006, pp. 41-65.

NAVAS GutiérREz 1993 - Antonio M. Navas Gutiérrez, Estudio preliminar, en: Vida de San Ignacio de Loyola en imágenes, Granada, Universidad de Granada, Facultad de Teología, 1993, pp. VIII-XLIX.

Nieto 2001 - Armando Nieto, Perú, en: Charles E. O’Neill, Joaquín María Domínguez (eds.) Diccionario Histórico de la Compañia de Jesús, Vol. III. Roma-Madrid, Institutum Historicum, Universidad Pontificia Comillas, 2001, pp. 3104-3111. 
Nuestra Señora de Cocharcas 2004 - Nuestra Señora de Cocharcas, en: Museo Pedro de Osma, [catalogo del Museo de Osma], Lima, Museo de Osma, 2004, pp. 86-87.

O’Malley 2014 [2013] - John W. O’Malley, Trydent, co się zdarzyto podczas soboru, trad. Marek Chojnacki, Kraków, Wydawnictwo WAM, 2014 [2013].

O'Phelan Godoy 2013 - Scarlett O'Phelan Godoy, Mestizos reales en el Virreinato del Perú: indios nobles, caciques y capitanes de mita, Lima, Fondo Editorial del Congreso del Perú, 2013.

PfeIfFER 2003 - Heinrich Pfeifer, Iconografía, en: Giovanni Sale (ed.) Ignacio y el arte de los jesuitas, Milán, Ediciones Mensajero. Editorial Jaca Book, 2003, pp. 169-206.

Pleguezuelo 2010 - Alfonso Plegezuelo, Luisa Roldán y la iconografía de Jesús Nazareno, en: Pedro Miguel Ibáñez, Carlos Julián Martínez Soria (eds.), La imagen devocional barroca, Cuenca, Ediciones de la Universidad de castilla-La Mancha, 2010, pp. 187-214.

SÁNCHez LóPEz 2010 - Juan Antonio Sánchez López, El Nazareno en la escultura barroca andaluza. Perspectivas de investigación desde la antropología, la iconografía y el arte, en: Pedro Miguel Ibáñez, Carlos Julián Martínez Soria (eds.), La imagen devocional barroca, Cuenca, Ediciones de la Universidad de castilla-La Mancha, 2010, pp. 111-186.

SCHENONE 2008 - Héctor Schenone, Santa María. Iconografía del Arte Colonial, Buenos Aires, Editorial de la Universidad Católica Argentina, 2008.

Stanfield-Mazzi 2013 - Maya Stanfield-Mazzi, Object and Apparition. Envisioning the Christian Divine in the Colonial Andes, Tucson, The University of Arizona Press, 2013.

VALENCIA EsPinOZA 1990 - Abraham Valencia Esponoza, Taytacha Temblores. Patrón jurado del Cuzco, Cusco, Centro de Estudios Andinos Cuzco CEAC, 1990.

Vega-Centeno 2006 - Imelda Vega-Centeno, Sollozos del alma. Confidencias con el Taytacha Temblores, "Revista Andina" 42 (2006), pp. 9-43.

Wiтko 2009 - Andrzej Witko, The Order of the Holy Trinity and Captives, trad. Ewa Świdzińska Lay y Kevin Lay, Kraków, Wydawnictwo AA, 2009.

Wiтко 2010 - Andrzej Witko, Jezus Nazareński Wykupiony, Kraków, Petrus, 2010.

Zaballa Beascoechea, Paniagua Pérez 2012 [2006] - Anna de Zaballa Beascoechea, y Jesús Paniagua Pérez, La Iglesia en Indias, en: Juan B. Amores Carredano (ed.) Historia de América, Barcelona, Editorial Planeta S.A., pp. 413-449. 


\section{Summary}

\section{Devotional representations in mission churches of the Mojos region (Boli- via) in the light of inventories of the epoch of expulsion}

The article presents three types of representations that may be found at the time of the Jesuits' exile in mission churches of the order in the Mojos region of Bolivia. The first group comprises devotional images typical of the Catholic Church, created in the post-Tridentine period; these are representations of Our Lady, Christ, Saints and biblical scenes. The second group consists of representations of figures associated with the Jesuit Order. While the third group includes representations and titles typical of the Viceroyalty of Peru, such as Señor de los Temblores, Virgen de Cocharcas and Nuestra Señora de Belén (from Cusco). All the titles have been determined on the basis of the inventories of 1767 , stored in Sucre in Archivo y Biblioteca Nacional de Bolivia (ABNB, signature: M y Ch, GRM, vol. 1, I and My Ch, GRM, vol. 1, III) and accounts from that period, which contain both information about the representations themselves and their frames associated with worship of the effigies. In the summary part, the objects concerned are presented in a broader context, both Peruvian, American and European one.

Keywords: Jesuit art, cult images, Jesuit missions, Mojos, Viceroyalty of Peru

\section{Streszczenie}

Przedstawienia dewocyjne w kościołach misyjnych regionu Mojos (Boliwia) w świetle inwentarzy z 1767 r.

W artykule zostały zaprezentowane trzy typy przedstawień, które odnaleźć można w momencie wygnania jezuitów w kościołach misyjnych zakonu znajdujących się w regionie Mojos w Boliwii. Pierwszą grupę stanowią wizerunki dewocyjne typowe dla Kościoła katolickiego powstające w epoce po soborze trydenckim. Są to przedstawienia Matki Boskiej, Chrystusa, świętych oraz sceny biblijne. Na drugą grupę składają się wizerunki postaci związanych z zakonem jezuitów. Do trzeciej grupy należą zaś przedstawienia i wezwania typowe dla obszaru Wicekrólestwa Peru, takie jak: Señor de los Temblores, Virgen de Cocharcas i Nuestra Señora de Belén (z Cusco). Jako podstawa do określenia wszystkich wezwań posłużyły inwentarze z 1767 r. przechowywane w Sucre w Archivo y Biblioteca Nacional de Bolivia (ABNB, sygnatura: M y Ch, Vol. 1, I i M y Ch, Vol. 1, III) oraz relacje z epoki, w których można odnaleźć zarówno informacje o samych przedstawieniach, jak i ich oprawie związanej z kultem wizerunków. W części podsumowania prezentowane obiekty zostały przedstawione w szerszym kontekście, zarówno peruwiańskim, amerykańskim, jak i europejskim.

Słowa kluczowe: sztuka jezuitów, wizerunek kultowy, misje jezuickie, Mojos, Wicekrólestwo Peru 